NBER WORKING PAPER SERIES

\title{
THE INFORMATION VALUE OF ONLINE SOCIAL NETWORKS: LESSONS FROM PEER-TO-PEER LENDING
}

\author{
Seth Freedman \\ Ginger Zhe Jin \\ Working Paper 19820 \\ http://www.nber.org/papers/w19820 \\ NATIONAL BUREAU OF ECONOMIC RESEARCH \\ 1050 Massachusetts Avenue \\ Cambridge, MA 02138 \\ January 2014, Revised February 2018
}

We would like to thank Larry Ausubel, John Haltiwanger, John Ham, Robert Hampshire, Anton Korinek, Phillip Leslie, Russel Cooper, Hong- bin Cai, Jim Brickley, Estelle Cantillon, Severin Borenstein, and various seminar attendants at Rochester, Toronto, Northwestern Kellogg, Columbia, University of Pennsylvania Wharton School, University of Maryland Smith School, 2010 NBER IO program meeting, Universiti Libre de Brux- elles, Katholieke Universiteit Leuven and the 2011 Conference on Gaming Incentive Systems for helpful comments. Chris Larsen, Kirk Inglis, Nancy Satoda, Reagan Murray and other Prosper personnel have provided us data support and tirelessly answered our questions about Prosper.com. Adam Weyeneth and other Prosper lenders have generously shared their prosper experience. We are grateful to the UMD Department of Economics, the Kauffman Foundation, and the Net Institute (www.netinst.org) for their generous financial support. An earlier draft has been circulated under the title "Do Social Networks Solve Information Problems for Peer-to-Peer Lending? Evidence from Prosper.com." This paper is independent of Prosper.com, all errors are our own, all rights reserved.

NBER working papers are circulated for discussion and comment purposes. They have not been peer-reviewed or been subject to the review by the NBER Board of Directors that accompanies official NBER publications.

(C) 2014 by Seth Freedman and Ginger Zhe Jin. All rights reserved. Short sections of text, not to exceed two paragraphs, may be quoted without explicit permission provided that full credit, including $(\odot$ notice, is given to the source. 
The Information Value of Online Social Networks: Lessons from Peer-to-Peer Lending Seth Freedman and Ginger Zhe Jin

NBER Working Paper No. 19820

January 2014, Revised February 2018

JEL No. D53,D82,L81

\begin{abstract}
$\underline{\text { ABSTRACT }}$
We examine whether social networks facilitate online markets using data from a leading peer-topeer lending website. We find that borrowers with social ties are consistently more likely to have their loans funded and receive lower interest rates; however, most borrowers with social ties are more likely to pay late or default. We provide evidence that these findings are driven by lenders not fully understanding the relationship between social ties and unobserved borrower quality. Overall, our findings suggest caution for using online social networks as a signal of quality in anonymous transactions.
\end{abstract}

Seth Freedman

School of Public and Environmental Affairs

Indiana University

1315 E. 10th St.

Bloomington, IN 47405

freedmas@indiana.edu

Ginger Zhe Jin

University of Maryland

Department of Economics

3115F Tydings Hall

College Park, MD 20742-7211

and NBER

jin@econ.umd.edu 


\section{Introduction}

Many online markets provide an infrastructure for anonymous individuals to conduct transactions with each other. To overcome the information asymmetries exaggerated by the anonymity, these markets often allow users to demonstrate social ties with other users on the same or related platforms. However, it is not well understood how effective anonymous social ties can be in helping to solve the information problems. Using transaction level data from Prosper.com - the first and by far the largest peer-to-peer consumer lending platform in the US ${ }^{1}$ - this paper examines whether or not informal online social networks can facilitate e-commerce when there are significant information asymmetries.

On Prosper.com individual borrowers and lenders are matched anonymously via real-time auctions. Although part of a borrower's credit history is disclosed to all lenders, online anonymity could exacerbate the classical information problems of consumer lending (Stiglitz and Weiss 1981). In an attempt to overcome some of these information problems, Prosper instituted social networking features. Prosper members can identify each other as friends and can join member created groups. Groups are intended to screen group-member borrowers before they post a listing and provide social pressure for their members to repay their loans. Friends and group leaders can also endorse a borrower by posting a message on the listing page, and bids from friends and group members are highlighted for other potential lenders to see. However, unlike typical microfinance arrangements (Armendariz and Morduch 2010), endorsement or group membership does not entail any co-signing responsibility or require any social interactions after funding. Lenders also cannot verify whether stated social ties exist outside of the platform.

Given borrower self-selection into non-verifiable social networks without explicit financial responsibility, borrower social networking attributes may convey positive or negative information about the borrower's true repayment probability or may simply reflect cheap talk with no additional information beyond other observable characteristics. We use loan application and repayment data from Prosper.com to understand what information these social networks convey about a borrower and how lenders tend to interpret these social networking attributes. We find that lenders are more likely to fund social network affiliated loans and give them lower interest rates.

\footnotetext{
${ }^{1}$ Zopa.com (of the UK) was the first peer-to-peer lending website world wide.
} 
However, not all social ties imply a higher financial return to lenders. In particular, only endorsements from friends who also contribute money to the loan themselves produce consistently better ex post repayment.

We explore a variety of potential explanations for this contrast between lender behavior and borrower repayment, all of which suggest that lenders misinterpret the information value of most social networking attributes. First, we find that different types of Prosper groups that seem more likely to provide better screening and monitoring do correlate with improved borrower quality, but lenders do not differentiate between many of these different types of groups in their funding decisions. This suggests that lenders find it difficult to distinguish high and low quality social networks. Second, we find evidence that some characteristics of the social networks on Prosper may have impeded lenders' ability to distinguish high-quality borrowers, particularly financial incentives for group leaders to endorse risky borrowers without performing adequate screening, and the ability of friends to provide each other mutual bids without exchanging real money. Third, we find that lenders respond to the repayment history of their past portfolio decisions and learn to avoid listings with misleading social network signals, including within their own social networks. This learning suggests that altruism is not likely to be the main driver of our results.

We also examine whether lenders share information with each other via their social networks. We find that lenders learn from the payment history of investments made by their group members in addition to what they learn from their own individual portfolios. This finding suggests that social networks can play a role beyond acting as a potential quality signal by acting as an information conduit for market participants.

Our work has important implications for understanding the role of information in online transactions and the extent to which social networks can help mitigate information asymmetries. The mixed evidence we have found about social networking on Prosper is consistent with the mixed effects of information on the internet in general. For example, price comparison websites can reduce search costs but obfuscate consumer search at the same time (Ellison and Ellison 2013); seller-provided product information can be a positive signal for seller quality in some eBay transactions (Lewis 2011), but confuse buyers in other situations (Jin and Kato 2007); online reputation can help to distinguish different types of sellers while motivating strategic retaliation (Dellarocas 2003); online crowd funding can help bring geographically distant funders to a project, but still may rely on local investors with offline ties to make initial investments (Agrawal et al. 2011); and social networks can facilitate 
targeted advertising but raise privacy concerns (Tucker 2011, 2012). All these studies, including ours, suggest that information is a double-edge sword, especially on the anonymous internet.

More specifically, our work highlights the challenges of importing ideas of microfinance to the online context in the developed world. Previous researchers have argued that informal and micro lenders have an information advantage over traditional banks because they utilize borrowers' social networks to ensure good risks (e.g. La Ferrara 2003, Udry 1994, Hoff and Stiglitz 1990, Besley and Coate 1995). However, most of the microfinance literature focuses on the contractual tools that lenders can use to improve loan performance, such as imposing joint liability among group members or organizing group meetings on a regular basis (Armendariz and Morduch 2010). Social networking on Prosper does not impose joint liability, and does not necessarily imply offline or regular contact among group members. Our work also differs methodologically. Lab and field experiments in microfinance are designed to randomly assign different contracts to similar borrowers, in order to minimize borrower selection into specific programs (Karlan 2005; Gine and Karlan 2010; Feigenberg, Field and Pande 2010; Bryan, Karlan and Zinman 2010). In contrast, we specifically study a context in which borrowers self-select into social networks ${ }^{2}$ with no contractual obligations. Our results suggest that self-selection, the lack of co-signing obligations, and non-verifiable social ties may hinder the effectiveness of social networks in online commerce.

As online social networking applications and websites have become more prominent, they have become increasingly integrated into commercial transactions. There have even been recent attempts to use social networking data from sites like Facebook, LinkedIn, and Twitter as an input into credit scoring (Rusli 2013, Wei et al. 2016). Our study suggests that online social ties should be interpreted with caution. They may not reveal true information about someone's unobserved credit worthiness and can potentially even be manipulated. That being said, contrasting our study with previous findings in microfinance suggests that if online friends are more actively involved in the process, such as Prosper friends who are willing to bid on a borrower's listing, there may be more value in extracting information from these ties. It is therefore important to ensure social ties have a tangible stake in the outcome that matters to lenders.

\footnotetext{
${ }^{2}$ Gomez and Santor (2003) compare individual and group borrowers in two Canadian microlenders and show that group borrowers tend to have smaller loans and are more likely to be female, Hispanic, immigrant, with lower income, etc. Ahlin (2009) shows that self-selected groups are more homogeneous than randomly assigned groups.
} 
Our paper also contributes to a growing literature on peer-to-peer lending itself (Ravina 2007, Pope and Sydnor 2011, Iyer et al. 2015, Rigbi 2011, Hampshire 2008, Freedman and Jin 2010, Lin et al. 2013, Paravisini et al. 2011, Kawai et al. 2013, Miller 2015), which focuses on either the relationship between borrower attributes and listing outcomes or lenders' investment decisions. Most directly related to our work, Iyer et al. (2015) find that Prosper lenders do use soft information in listings to their advantage in screening loans. They find that interest rates granted by lenders on Prosper more accurately predict default rates than exact credit scores that the lenders do not have access to. Our paper explores directly how lenders respond to a particular type of soft information represented by social networks. Hildebrand et al. (2016) find that some group leaders on Prosper use bidding behavior to take advantage of lenders in order to receive group leader rewards. Our results on how the impacts of group related social ties changed after group leader rewards were discontinued confirms these findings. Lin et al. (2013) find that Prosper borrowers with friends are more likely to be funded and loans with funding from friends have lower default rates. Our paper complements these other studies by considering group and friend characteristics together, quantifying the effects of social networking attributes on a measure of the internal rate of return that accounts for both differences in interest rates and payoff patterns, and explores potential mechanisms that would lead to the patterns of lender behavior and loan outcomes observed in the data.

The rest of the paper is organized as follows. Section 2 describes the background of Prosper.com, its social networking features, and our data. Section 3 examines the effect of borrower social ties on funding probability, interest rate, repayment patterns, and an estimated internal rate of return. Section 4 explores a variety of potential mechanisms behind our main findings. A short conclusion is offered in Section 5 .

\section{Background, Data, and Summary Statistics}

The Prosper website is designed to match lenders and borrowers through an online auction similar to how eBay matches buyers and sellers of a product. In this section we describe the basics of the marketplace's design, the social networking tools Prosper employs, the structure of our data, and summary statistics.

\subsection{The Prosper Marketplace}

All Prosper loans are fixed rate, unsecured, three-year, and fully amortized with simple interest, and they range from $\$ 1,000$ to $\$ 25,000$. Prosper reports repayment 
to credit agencies, and if a loan defaults Prosper hires collection agencies and returns any money retrieved in collections to the loan's lenders. ${ }^{3}$ By the end of our sample period (July 31, 2008), Prosper had attracted 750,000 members and originated loans of over 160 million dollars. ${ }^{4}$

During our study period, potential Prosper borrowers can post an eBay-style listing specifying the maximum interest rate she is willing to pay, the requested loan amount, and the duration of the auction (3-10 days). The borrower can also choose to close the listing immediately after it is fully funded (called autofunding) or allow further bidding on the interest rate until the auction window ends. In addition to the auction parameters, the borrower may describe herself, the purpose of the loan, and post an image. Prosper also posts hard credit information extracted from Experian credit reports. While Prosper's agreement with Experian disallows it from posting exact credit scores, it does post credit grade categories that include AA defined as 760 or above, $\mathrm{A}$ as $720-759, \mathrm{~B}$ as $680-719, \mathrm{C}$ as $640-679, \mathrm{D}$ as 600639, $\mathrm{E}$ as 540-599, HR as less than 540, and NC if no credit score is available. ${ }^{5}$ Additional hard information changed slightly during our study period, with changes listed in plain text in Table 1. At the beginning of our sample (June 2006), this information included debt-to-income ratio, ${ }^{6}$ whether the borrower owns a home, and some credit history information about delinquencies, credit lines, public records, and credit inquires. On February 12, 2007, Prosper began posting more detailed credit history information plus self reported income, employment and occupation. ${ }^{7}$ On October 30, 2007, Prosper began to display a Prosper-estimated rate of return on the bidding page. Before this change, a lender had to visit a separate page to research historical performance of similar loans.

Lenders can browse listing pages which include all of the information described above, plus information about previous bids placed by other lenders, the percent of the listing's requested amount that has been funded to date, and the listing's current prevailing interest rate, as determined by the auction mechanism described below. To

\footnotetext{
${ }^{3}$ There is no penalty for early payment.

${ }^{4}$ The quick expansion of Prosper coincided with a number of similar new peer-to-peer lending sites in the US. The best known examples are Kiva.org (incorporated November 05), Smava (launched in February 2007), Lending Club (opened May 24, 2007 as part of Facebook), MyC4 (launched in May 2007), Globefunder (launched in October 2, 2007), and Zopa US (us.zopa.com, opened December 4, 2007).

${ }^{5}$ On Feb 12, 2007 Prosper tightened the definition of grade E from 540-599 to 560-599 and grade HR from less than 540 to 520-559 eliminating borrowers that have no score or a score below 520 .

${ }^{6}$ The debt information is available from the credit bureau, but income is self-reported.

${ }^{7}$ On this date, lenders were also allowed to begin asking borrowers questions and the borrowers had the option to post the Q\&A on the listing page.
} 
view historical market data, a lender can download a snapshot of all Prosper records from Prosper.com (updated daily), use a Prosper tool to query desired statistics, or visit third party websites that summarize the data. Interviews conducted at the 2008 Prosper Days Conference suggest that there is enormous heterogeneity in lender awareness of the data, ability to process the data, and intent to track the data over time.

The auction process is similar to proxy bidding on eBay. A lender bids on a listing by specifying the lowest interest rate he will accept and the amount of dollars he would like to contribute (any amount above \$50). A listing is funded if the total dollar amount of bids equals or exceeds the borrower's requested loan amount by the end of the auction window. If the total dollar amount bid is greater than the requested amount, the lenders with the lowest specified minimum interest rate will fund the loan, and the contract interest rate is set as the minimum interest rate specified by the first lender excluded from funding the loan. ${ }^{8}$ Prosper charges fees on both sides of the market if a listing is completely funded. Freedman and Jin (2010) discuss additional details of the market operation.

Prosper makes all of its listing and loan data available for download from its website. Our main data set comes from the data available for download as of August 18, 2011. Because of changes to the platform that occurred in the second half of 2008, we analyze the sample of all listings posted between June 1, 2006 and July 31, 2008 and the loans that originate from this set of listings. ${ }^{9}$ Our data extract includes all of the information available to borrowers and lenders described above. For those listings that become loans, we observe payment through July 31, 2011, which includes the full 36-month history for all loans in our sample. We also observe data on bids, which allows us to construct and track each lender's portfolio through time.

Table 2 summarizes listings and loans by quarter for our sample, which includes 293,808 listings and 25,008 loans for $\$ 158.27$ million. This implies an average funding rate of $8.51 \%$, though this varies over time ranging from $6.32 \%$ to $10.14 \%$. Average listing size and average loan size both increased through the first half of 2007 and decreased afterward. Comparing listings and loans, the average listing requests $\$ 7,592$ and the average loan is worth $\$ 6,329$. The average listing lists a maximum borrower

\footnotetext{
${ }^{8}$ If autofunding is chosen by the borrower, the auction ends immediately upon becoming fully funded, and the interest rate is set at the borrower maximum rate.

${ }^{9}$ We exclude the few loans that were suspects of identity theft and as a result repurchased by Prosper.
} 
rate of $19.19 \%$ while the average contract rate is $17.90 \% .^{10}$

\subsection{Social Networks}

Prosper implements social networking through "groups" and "friends." These social network features have a variety of intended roles on the site including recruitment of new members to the site and as a means of facilitating Prosper transactions. It is worth noting that Prosper was a pioneer in using social ties in peer-to-peer lending. Thus the evolution of Prosper's social networking policies is likely a result of multiple factors, including platform experimentation, the time lag of loan outcome data, and the platform's desire to grow quickly on both the borrower and lender side of the market. ${ }^{11}$ Here we discuss the basics of these social networking features and their role in the lending process. Changes to social network related policies described in this section are listed in italic text in Table 1.

Any non-borrowing Prosper member may set up a group and become a group leader. Group leaders determine which other Prosper members can join the group, and it is at the discretion of the leader how narrow or broadly to define eligible membership and how to monitor and enforce membership requirements. Each member of Prosper can join at most one group.

The group leader's intended responsibilities include setting up the group profile page, recruiting new members into the group, coaching the members of the group interested in borrowing on how to construct a Prosper listing, and monitoring the performance of the listings and loans of group members. The group leader does not have any legal responsibility for loans to its members. Rather, the group leader is supposed to foster a "community" environment within the group.

To the extent that the group leader knows the borrower in other contexts (e.g. colleagues, college alumni, military affiliation), she could collect credit-related information via emails, interviews, house visits, employment checks, and other laborintensive means. ${ }^{12}$ However, many groups are very large (some with over 10,000 members), and this monitoring and direct social pressure likely varies a great deal between groups. Starting October 19, 2006, Prosper began posting star ratings (one to five) to indicate how well a group's past loans had performed. ${ }^{13}$

\footnotetext{
${ }^{10}$ The sharp increase in borrower maximum rates between the first and second quarters of 2008 reflects the April 2008 removal of state specific interest rate caps for some states.

${ }^{11} \mathrm{~A}$ two-sided market like Prosper enjoys positive network externalities when one or both sides of the market expand quickly (Rochet and Tirole 2006, Rysman 2009).

${ }^{12}$ Group leaders do not have access to the borrower's credit report prior to listing.

${ }^{13}$ Groups must have at least 15 loan cycles billed before they are rated, otherwise they are "not yet rated."
} 
Despite the initial intentions, originally group leaders may have faced perverse incentives. Prosper groups were partially initiated as a tool to expand the market, and thus Prosper initially rewarded a group leader roughly $\$ 12$ when a group member had a loan funded (Mendelson 2006). The group leader reward may have created a perverse incentive to recruit borrowers without careful screening of credit risk. This tension between member recruiting and performance monitoring prompted Prosper to discontinue group leader reward on September 12, 2007.

Starting on February 12, 2007, Prosper members could invite their friends to join the website. The inviting friend receives a reward when the new member funds $(\$ 25)$ or borrows her first loan $(\$ 50)$. Existing Prosper members can become friends as well if they know each other's email address, though the monetary reward does not apply. In either case, both parties must agree to being distinguished as friends.

Groups and friends can use two tools to try to influence whether a group member's or friend's listing becomes funded. First, group leaders and friends can provide an "endorsement" on a member's listing. These endorsements are displayed on the listing page along with an optional statement from the endorser about why someone should bid on the borrower's loan. Only the group leader of the borrower's group and friends of the borrower can make these endorsements. In addition to endorsements, any bids from group leaders, group members, or friends are highlighted in the list of previous bids. These are intended to signal to other potential lenders that the borrower's group leader, group members, and/or friends are interested in contributing to the loan. In our analysis below we focus on friend and group leader endorsements that do and do not have accompanying bids. However, leaders and friends can also bid without making an endorsement. ${ }^{14}$

While we observe friend and group leader endorsements directly in the listing data downloaded from Prosper, we only observe group membership or friendship networks that are in place on the date of download. Because these characteristics can change over time, we use monthly downloads from January 2007 to July 2008 to construct measures of group membership and friendship networks at the closest possible date to an actual listing that a borrower posts or on which a lender bids.

Table 2 shows that $28.8 \%$ of listings have some group affiliation, $3.2 \%$ have an endorsement from a group leader (2.2\% with a leader bid), and $13.0 \%$ receive a friend endorsement (1.0\% with a friend bid). All of these fractions are substantially

\footnotetext{
${ }^{14}$ Beginning February 23, 2008 lenders could include aspects such as friend endorsements and bids from friends as explicit criteria in listing searches, rather than having to browse through listings to find these characteristics.
} 
higher in the loan sample, indicating that on average social loans are more likely to be funded than the listings that have no social ties. However, it is striking that the proportion with group affiliation decreased drastically over time from a peak of $62 \%$ to $7.5 \%$ for listings and from $71 \%$ to $11 \%$ for loans. Likewise, the percent of listings with group leader endorsement and bid declines sharply from $4.10 \%$ in the third quarter of 2007 to $0.84 \%$ in the next quarter. Similarly, the percent of loans with group leader endorsement and bid declines sharply from $23.40 \%$ to $6.44 \%$ in the same time frame, around the time when group leader rewards were removed. No such declines appear for listings or loans with group leader endorsement but without group leader bid. When friend endorsements became available, the percent of listings and loans with endorsements initially grew but decreased after the middle of 2007, particularly those endorsements without accompanying bids.

Table 3 summarizes more details of group attributes. We classify groups by size (numbers of total members, both borrowers and lenders), composition (percent of members who are borrowers), type (alumni, military, tangible connections such as employment or geographic location, loose connections such as religion or ethnicity), ${ }^{15}$ and whether the group leader chooses to require borrower listings by group members to be reviewed prior to posting. Beginning October 19, 2006, we also observe whether a group borrower is affiliated with a group of low (1-3 stars), high (4-5 stars), or no group rating. Comparing the samples of listings and loans, it is clear that smaller groups, especially those with fewer borrowers, are more likely to be funded. Listings affiliated with high group ratings, alumni groups, groups of tangible connections, or groups with review requirement are more likely to be funded, but listings from military groups or groups of loose connections are less likely to be funded. Table 3 also summarizes Prosper loans by source of funding. It is clear that most funding comes from stranger lenders, with friends, group members and group leaders contributing only $1-5 \%$ of the total loan amount.

Table 4 more directly compares listing and loan characteristics and outcomes by social networking attributes. The correlation between social networking attributes and observable borrower characteristics is complicated. Listings with some social ties, including endorsements with bids from friends and group leaders are much less likely to have low credit grades, while listings with other social ties, such as group membership are more likely to have low credit grades. However, among funded loans

\footnotetext{
${ }^{15}$ To classify group type, we read the full description of each group (supplied by group leader when he/she sets up the group) and create indicators if the group description shows clear focus on alumni, military, employment, geographic location, religion or ethnicity.
} 
borrowers with social ties are consistently more likely to have lower credit grades, suggesting lenders are more likely to fund loans of low observable credit worthiness as a result of social networks.

Overall, funding rates are higher for listings with social ties, particularly listings with endorsements and bids from friends and group leaders. The pattern of contract interest rates are less consistent, as they are likely confounded by differences in observable characteristics, but loans with friend endorsement and bids are rewarded with the lowest contract rate. Turning to summary measures of repayment, loans with social ties tend to have higher rates of default or late payments, except for friend endorsement with bid. We explore these patterns in more detail in the following section where we disentangle the relationship between social networking attributes and listing and loan outcomes, conditional on other observable characteristics.

\section{Social Networks, Lender Funding Decisions, and Loan Outcomes}

The primary goal of this paper is to examine what information a borrower's social network affiliation conveys and how lenders interpret this information. Since a borrower chooses which networks to join on Prosper, social networking behavior may convey some information that the borrower knows but a typical Prosper lender does not know. All else equal, a borrower with social ties may be of true lower quality or higher quality than a borrower without social ties. Alternatively, joining a social network may be cheap talk that conveys no true information. Regardless of the underlying true information, lenders may correctly or incorrectly interpret the information value of loans when making their funding decisions. We first estimate the relationship between social networking attributes and the likelihood a listing is funded and the interest rate in order to understand how lenders interpret borrower social networking attributes. We then explore whether lender decisions are in line with true borrower quality as revealed by repayment history. In the next section we consider potential explanations of the relationships we find.

\subsection{Effects of Social Network Attributes on Funding and Interest Rates}

Summary statistics suggest that on average borrowers with social networking characteristics are rewarded by lenders with higher funding rates and lower interest rates. In this section, we explore these relationships conditional on other borrower observable characteristics. An important distinction between our empirical approach and previous studies in microfinance is that we are not necessarily attempting to 
estimate the effect of randomly assigned monitoring/screening networks on outcomes. Instead we are interested in conditioning on all observable characteristics that the lender sees in a listing and quantifying what additional information lenders interpret from social network attributes. This additional information may be correlated with unobservable borrower characteristics, but what we are interested in is how social networks are used as a proxy for the borrower's unobserved quality.

One caveat is that there could be information that is both correlated with social networking status and observed by lenders, but that we are unable to control for in the econometric analysis. These characteristics could include qualitative information in the borrower's picture or text that we cannot quantify in the data. For example, others have found the physical appearance of borrowers in Prosper images, including race, beauty, and trustworthiness, to be important determinants of lender funding decisions (Pope \& Sydnor 2011, Duarte et al. 2012, Ravina 2007). To minimize this concern, we control for the presence of a picture, the length of the text, and whether the text mentions certain loan purposes such as paying for medical bills, starting a business, or purchasing a car. We have also conducted robustness checks where we restrict our sample to a set of listings and loans with homogeneous image content namely those without an image - and find a very similar pattern of results to what we present in this section. ${ }^{16}$

We estimate the relationship between social networking attributes and listing outcomes with the following two regression equations:

$$
\begin{aligned}
1\left(\text { Funded }_{i t}\right. & =f_{1}\left(\text { SocialVar }_{i}, \text { ListingAttributes }_{i}, \text { macro }_{i t}, Y W_{t}\right)+\varepsilon_{1 i t} \\
\text { ContractRate }_{l t} & =f_{2}\left(\text { SocialVar }_{l}, \text { ListingAttributes }_{l}, \text { macro }_{l t}, Y W_{t}\right)+\varepsilon_{2 l t}
\end{aligned}
$$

Equation 1 includes the full sample of listings and describes whether or not listing $i$ created at time $t$ is funded or not $\left(1(\text { Funded })_{i t}\right)$. Equations 2 includes the listings of fully funded loans and describe the contract interest rate (ContractRate Cof $_{\text {) }}$ of loan $l$ funded at time $t$. These regressions include year-week fixed effects $\left(Y W_{t}\right)$ and macroeconomic conditions that vary by day or by the borrower's state of residence (macrolt $_{\text {) }}$ to control for the changing environment on and off Prosper at the time of funding. ${ }^{17}$ ListingAttributes include Experian-verified credit history information,

\footnotetext{
${ }^{16}$ These results are presented in Appendix Table 3 and are very similar to the results of Table 5 discussed in this section.

${ }^{17}$ To capture the growth and fluctuation of the Prosper market as a whole, we also control for a number of daily Prosper-specific market characteristics, including the total value of active
} 
borrower-specified loan terms (e.g. amount requested and maximum interest rate), and borrower self-reported information (e.g. loan purpose, image, description). ${ }^{18}$ Summary statistics of these attributes can be found in Appendix Table 1. The listing attributes and the macroeconomic variables are also interacted with credit grade dummies.

The parameters of interest are the coefficients on the variables in SocialVar. In the baseline specification these include indicators for the borrower being in a group, having a group leader endorsement with no bid, having a group leader endorsement with a bid, having a friend endorsement without a bid, and having a friend endorsement with a bid. The funding rate regression is estimated by probit, and the contract rate regression is estimated by OLS.

Columns 1 and 2 of Table 5 presents the estimated effects of the social network variables from the above specifications, with coefficient estimates reported for linear regressions and marginal effects for probit estimates. All else equal, listings in which the borrower belongs to a group are 0.2 percentage points more likely to be funded and enjoy a 0.4 percentage point lower contract rate, suggesting that lenders interpret group affiliation as containing positive information about borrower quality.

Both types of group leader endorsements appear to be interpreted as additional positive information by lenders. Both lead to higher funding rates and lower contract interest rates in the second and third rows of Table 5, particularly those with an accompanying bid.

The final two rows of Table 5 explore friend endorsements with and without bids. As with group leader endorsements, friend endorsements increase the likelihood a listing is funded, and the effect is larger when the endorsement is accompanied by a bid. Loans with a friend endorsement alone are 0.1 percentage points more likely to be funded than non-friend endorsed loans, but when the endorsement is accompanied by a bid, the funding probability is 3.4 percentage points higher than non-friend endorsed loans. Friend endorsements without bids lead to 0.1 percentage point higher contract rates and friend endorsements with bids lead to 0.6 percentage point lower contract rates.

To this point, our estimates suggest that, conditional on observed borrower char-

loan requests by credit grade, the total dollar amount of submitted bids by credit grade, and the percentage of funded loans that have ever been late by credit grade.

${ }^{18}$ We only include observable credit information that was available for our whole sample period and not those new credit variables added after Feb. 12, 2007. Results are similar if we restrict the sample to post February 12, 2007 and include these additional variables and are available from the authors upon request. 
acteristics, lenders are more likely to fund and agree to lower interest rates for borrowers with most social ties.

\subsection{Social Network Attributes and Loan Outcomes}

In this section we explore whether loans with social networking attributes are in fact lower risk loans. To assess this we estimate the following three regressions:

$(3) 1\left(\right.$ DefLate $_{l t a}=f_{3}\left(\right.$ SocialVar $_{l}$, ListingAttributes $_{l}$, macro $_{l t}, Y W_{t}$, Age $\left._{a}\right)+\varepsilon_{3 l t a}$

$(4) 1\left(\right.$ PaidOff $_{l t a}=f_{3}\left(\right.$ SocialVar $_{l}$, ListingAttributes $_{l}$, macro $_{l t}, Y W_{t}$, Age $\left._{a}\right)+\varepsilon_{3 l t a}$

$$
I R R_{l t}=f_{4}\left(\text { SocialVar }_{l}, \text { ListingAttributes }, Y W_{t}\right)+\varepsilon_{4 l t}
$$

Regression Equations 3 and 4 include all funded loans and follow the payment history of each loan over its 36-month life span. The dependent variables measure whether or not loan $l$ at time $t$ and age $a$ is default or late in Equation 3, and whether it is paid off in Equation 4. These regression ask whether loans with social networking attributes have different payment patterns than loans without social networking attributes, conditional on observable loan characteristics and the age of the loan.

Regression Equation 5 explores the impact of social networking attributes on a loan's internal rate of return (IRR), a summary measure of loan performance that incorporates both payment patterns and interest rate. Arguably, if the goal of lending on Prosper is to maximize financial returns, a lender should consider interest rate and expected repayment together in making lending decisions. To construct this measure, we use all available ex post repayment data to calculate the IRR that a sophisticated lender should expect to earn at the start of a loan if he could perfectly predict the statistical relationship between listing attributes and ex post loan repayment.

One complication is that the macroeconomic environment changed substantially during our study period due to the concurrent financial crisis. To address this problem, we follow a two step algorithm: first, we estimate how ex post loan repayment patterns of all Prosper loans relate to listing attributes and macroeconomic variables at the time of payment. ${ }^{19}$ This estimation attempts to isolate the contribution

\footnotetext{
${ }^{19}$ Macroeconomic variables include daily measures of the bank prime rate, the TED spread, the yield difference between corporate bonds rated AAA and BAA, and S\&P 500 closing quotes. Additionally, we include the unemployment rate reported by the Bureau of Labor Statistics (BLS) by state and month, the housing price index reported by the Office of Federal Housing and Enterprise Oversight (OFHEO) by state and quarter, the quarterly percentage of senior loan officers that
} 
of macroeconomic variables to realized loan repayment from the fundamental risk described by listing attributes. The second step predicts the pattern of payments using the coefficient estimates from the first step but substituting the macroeconomic variables as of June 1, 2006 for the real macroeconomic variables. Based on the predicted payment flows, we calculate an internal rate of return (IRR) that the lender should expect to earn from each loan if the macroeconomic environment were fixed at the beginning of our sample period (June 2006). The detailed algorithm, IRR calculation, and the robustness of this calculation to alternative definitions of IRR are reported in the Appendix.

By definition, the effect of social ties on IRR depends on contract rates and repayment. If the Prosper market operates efficiently and lenders correctly interpret social ties, we would expect to find differences in payment outcomes but no differences in returns between social and non-social loans, as any difference in payment patterns would be reflected by different contract rates. If we instead observe that lenders with social ties have lower (or higher) IRRs than non-social loans, it would suggest lenders under (or over) price social loans. Therefore, we can compare results of the relationship between a social networking attribute and funding, contract rate, repayment, and IRR to understand the extent to which lenders appropriately take into account the information conveyed by that characteristic. For example, if we find that a particular characteristic improves the funding rate, lowers the contract rate, reduces the default rate, and improves the IRR, we would infer that characteristic conveys positive information about the borrower's quality, the lenders correctly interpret that these borrowers have higher quality, but lenders incorrectly interpret the magnitude of this quality differential. If they did fully understand the quality difference, they would compete away the IRR difference through even lower contract rates.

Figures 1 through 3 compare the IRR density and mean IRR over time for borrowers with and without social networking attributes. In Figure 1A it is clear that the IRR distribution of group borrowers has a thicker left tail than that of non-group borrowers. Figure 1B plots mean IRR by group affiliation over time, with mean IRR always being lower for group borrowers. These relationships are less clear when splitting borrowers by whether or not they have a group leader endorsement but no bid, a group leader endorsement and bid, or no group leader endorsement in Figure 2A and $2 \mathrm{~B}$. Loans with an endorsement and bid from the group leader appear to have

have eased or tightened credit standards for consumer loans, and the foreclosure rate reported by Realtytrac.com by state and month. 
lower IRR's, especially in the earlier time period.

The relationship between friend endorsement status and IRR is shown in Figure $3 \mathrm{~A}$ and $3 \mathrm{~B}$. On average, borrowers with a friend endorsement and no bid have lower IRRs than borrowers with no friend endorsement, while borrowers with a friend endorsement and bid have higher IRRs. These unadjusted mean comparisons suggest that while most social networking attributes are rewarded by lenders in terms of funding rate and interest rate, not all are associated with equal or higher returns.

Regression estimates of Equations 3, 4 and 5 are presented in Columns 3-5 of Table 5. Group member loans are 0.6 percentage points more likely to be default or late in a given month and 0.4 percentage points less likely to be paid off early. When we summarize overall return, accounting for the contract rate and payment patterns with our measure of IRR, group loans have a 1.8 percentage point lower expected rate of return than non-group loans. These regression results are similar to the unconditional comparisons in Figures 1A and 1B. Taken together with the previous result that group membership increases the funding rate and decreases the contract rate, these results suggest that group membership in fact holds negative information content about borrowers, but lenders incorrectly interpret group membership positively.

The effect of a group leader endorsement on loan outcomes depends on whether the group leader also bids on the listing: if a group leader endorsement is not accompanied by a bid, the loan has a similar default rate to non-endorsed loans and is less likely to be paid off early, leading to a 1.9 percentage point higher IRR. In contrast, if a loan has both an endorsement and a bid from the group leader, it is more likely to be default or late, but less likely to pay off early. On net, group leader endorsement with a bid leads to a 1.3 percentage point lower IRR than nonendorsed loans. ${ }^{20}$ These results suggest that while lenders interpret both types of endorsements as positive information, only group leader endorsements without bids actually predict better loan outcomes. We explore this counterintuitive finding below by examining how the effects of these variables change after the elimination of group leader rewards.

Controlling for other listing attributes, a friend endorsement without a bid is more likely to be default or late and less likely to pay off early, leading to a statistically significant 0.8 percentage point lower IRR. In contrast, loans with friend

\footnotetext{
${ }^{20}$ Note that IRR accounts for the exact timing of each event in each loan, while the repayment outcome regressions only control for timing via the 36 monthly loan age dummies. Because of this, the impact of a particular loan attribute on IRR is more complicated than the sum or average of the attribute's impact on separate payment measures.
} 
endorsements and accompanying bids are 4.1 percentage points less likely to be in default or late. However, lenders do not completely compete away these gains as IRR is 6 percentage points higher than loans without friend endorsements. Interestingly, friend endorsement with a bid is the only social attribute examined thus far that also has an unconditionally higher IRR on average as seen in Figure 3B. In the raw data, these loans have higher IRRs due to their concentration of higher grade loans, but even conditioning on observable loan attributes, friend endorsement plus bid appears to convey additional borrower quality that has not been priced by the market.

\section{Potential Mechanisms}

In this section we explore potential explanations for the finding that lenders favor loans with social ties, despite most social ties being correlated with worse loan outcomes.

\subsection{Do Lenders Distinguish Between Heterogeneous Groups?}

We have found that the average group listing is more likely to be funded, but the average group loan results in lower returns. However, certain types of groups may be more or less likely to provide screening and monitoring of group members. We therefore explore whether different types of groups have different impacts on loan outcomes, and whether lenders distinguish between these different types. It could be the case that some types of groups do provide additional information about a borrower's quality, but lenders are unable to determine which groups carry this information and which do not.

Table 6 considers the sample of group member listings and tests whether various attributes of groups are associated with better loan outcomes and how lenders respond to these additional attributes. In particular we add measures of group ratings, group size, group composition, group type, and whether the leader reviews listings. ${ }^{21}$ If groups provide some level of screening or monitoring, we might expect better borrower risk if the borrower is affiliated with a group with better past loan payment histories (measured by a higher rating), a smaller group, a group that is composed of a larger concentration of lenders, a group that is indicative of more tangible connections, or a group in which the leader must review the credentials of its borrowers.

\footnotetext{
${ }^{21}$ Variables for group and friend endorsements are also included in this regression, but excluded from the table to save space. The coefficient estimates on these variables are similar to those in other specifications presented.
} 
The results in Table 6 are mixed. Relative to group listings prior to ratings becoming available, lenders are less likely to fund listings with no rating or a low rating, although ratings do not seem to correlate strongly with subsequent loan payment rates. Rated group loans do have higher IRRs than unrated group loans; however, the number of stars itself does not appear to correlate strongly with IRR. Because unrated groups are newer, this finding suggests that less established groups lead to a lower return. ${ }^{22}$

There are important differences by group size and composition in the direction that suggests borrowers from smaller and less borrower oriented groups have better loan outcomes. Compared to loans affiliated with groups of more than 1000 borrowers, loans from smaller groups have lower default rates. Lenders recognize that borrowers from smaller groups are likely to have better repayment rates, since these small groups also have the highest funding rates. However, lenders do not fully incorporate this better repayment rate into the contract rate, as the smallest groups of fewer than 100 borrowers have substantially higher IRRs than other groups. Compared to loans affiliated with a group in which more than $75 \%$ of members are borrowers, loans from less borrower-oriented groups are also much less likely to be default or late and have much higher IRRs. That said, this characteristic may not be identified by lenders as there is no clear pattern of funding or interest rates by group composition. Lenders appear to respond somewhat to the overall size of the group, but not the lender-borrower composition of groups, despite both being strongly correlated with loan outcomes.

We also attempt to classify groups by their type of connection. Offline connections may imply additional screening and monitoring, or they may simply verify a certain borrower attribute. For example, members of a university alumni group may not know each other in person, but group membership certifies the borrower's educational attainment. Similarly, membership in an employment related group, such as the Walmart Employee group, certifies a member's employment status if the group leader verifies employment. While we cannot disentangle these impacts, it is interesting to explore the extent to which the type of connection impacts group loan outcomes and lender interpretation.

The results suggest that groups with tangible offline connections have better loan outcomes. Loans of alumni groups or other offline connections such as common

\footnotetext{
${ }^{22}$ In results not shown, we find similar patterns when we include group fixed effects in this regression. This specification identifies the effect of star ratings as groups move from having no rating to a low or high rating once they have enough history to be rated.
} 
employment, geographic, or other personal connections are less likely to be default or late and deliver higher IRRs. Looser connections such as ethnicity or religion have similar effects, but smaller in magnitude. That said, lenders do not appear to respond to these differences in terms of funding rates or interest rates except a slightly lower interest rate for loosely connected groups. In contrast, military related groups are associated with lower funding rates, higher rates of default or late, and lower IRRs relative to other groups. This suggests that lenders view military connections as an indicator of higher risk.

Lastly, loans affiliated with a group that requires the group leader to review listings are more likely to be funded and less likely to be default or late if funded, though their contract rates are slightly higher and IRRs are statistically similar to those without review requirement. Lenders appear to interpret reviewed group members as higher quality, and lower default rates appear to be competed away and returns are equalized.

Overall, these results suggest a great deal of heterogeneity among group borrowers. Some types of groups appear to hold more information content than others. While lenders are more likely to fund borrowers from smaller groups, which also appear to have better payment outcomes, lenders do not tend to differentiate between different group types in their lending decisions. This finding suggests that lenders cannot distinguish groups that are more or less likely to provide screening and monitoring.

\subsection{Do Perverse Incentives Lead to Lender Confusion?}

It is possible that some characteristics of the Prosper marketplace increase the likelihood that lenders misinterpret social networking attributes. First, group leader rewards (about $\$ 12$ per new loan) may encourage group leaders to recruit as many borrowers as possible, endorse the group's listings to ensure funding, but engage in no screening or monitoring. ${ }^{23}$ These incentives should have been reduced after Prosper eliminated the group leader rewards in September 2007. Second, friends have the ability to provide each other mutual endorsements. Two borrowers may agree to endorse each other or even bid on each other's listings with effectively no actual monetary exchange. On average, $11.46 \%$ of listings and $16 \%$ of loans with a friend endorsement are involved in a mutual endorsement and $6 \%$ of listings and loans with

\footnotetext{
${ }^{23}$ Prosper did hold back a portion of the $\$ 12$ group leader reward until the loan had some payment history.
} 
an endorsement and bid are involved in a mutual endorsement and bid. ${ }^{24}$ If borrowers recognize these perverse incentives, but lenders do not, low quality borrowers may seek social ties in order to take advantage of misinformed lenders.

Table 7 tests these two types of gaming by adding five additional dependent variables: a dummy of whether a group listing is after the group leader rewards were removed, dummies for whether each type of group endorsement occurred after leader rewards were removed, a dummy of whether the listing has a mutual endorsement but without bids, and a dummy of having a mutual endorsement and mutual bid. Group listings are equally likely to be funded before and after rewards were removed; although, lenders demand higher interest rates from group related loans in the latter period. Group loans after rewards are removed have lower default rates and higher IRRs than group loans in the earlier period. This finding, combined with the previous findings that the percent of listings and loans associated with groups and with group leader endorsements dropped dramatically in the fourth quarter of 2007, suggests that the removal of group leader rewards reduced gaming by group leaders.

We also interact the group leader endorsement variables with a dummy for loans occurring after leader rewards were removed. The repayment and IRR advantage of loans with group leader endorsements alone, as compared to group loans with no leader endorsement, is reduced in the post leader reward period, while loans with group leader endorsements and bids see no additional change. ${ }^{25}$ This finding suggests that the types of loans that group leaders chose to endorse and/or bid on changed when leader reward were no longer available.

Table 7 shows that mutual endorsement combined with mutual bidding is associated with little change in funding rate and contract rate, but significantly lower IRRs. Note that the negative coefficient of mutual endorsement and bid on IRR (-1.2 percentage points) is compared to loans with friend endorsement and bid in one direction only. Because loans with friend endorsement and bid are associated with 6.1 percentage points higher IRRs than non-social loans, on net loans with mutual friend endorsement and bid still have significantly better payment rates and IRRs than non-social loans. Interestingly, loans with a mutual endorsement and bid are also associated with a lower probability of being default or late, which suggests that the negative effect on IRR is driven by more of these loans paying off early. In comparison, mutual endorsement without a bid increases the funding rate, but

\footnotetext{
${ }^{24}$ For both mutual endorsements with and without bids, the median number of days between the two endorsements is around 30 days, suggesting many occur within a short time window.

${ }^{25}$ These results are consistent with Hildebrand et al. (2016).
} 
it has no statistically significant effect on other outcomes. Therefore, these mutual endorsements without a bid do not add any additional negative risk beyond friend endorsement without bid on its own. Overall, we conclude that there is evidence of gaming due to group leader reward incentives, but only limited evidence of gaming through mutual friend endorsement and bidding.

\subsection{Are Lenders Profit Maximizing or Altruistic?}

Our results to this point strongly suggest that lenders are more likely to fund and provide lower interest rates to loans with social networking attributes, despite many of these loans being less likely to repay on time. Our results on group heterogeneity and gaming suggest that lenders may not fully distinguish between social loans that convey true quality information and those that do not. These patterns are consistent with either lenders making mistakes in their interpretation of social networks or with lenders having objectives aside from profit maximization. In particular, it is possible that social network affiliation could increase funding rates, decreases contract rates, and be associated with worse loan outcomes if some lenders are motivated to fund Prosper loans by altruism. Freedman and Jin (2010) document that, in addition to social network affiliated loans, lenders invest in many categories of loans that produce lower returns on average. However, additional findings suggest that lenders learn from the default and late paying loans of their initial investments and subsequently target higher return loans. This pattern suggests that lenders learn from their "mistakes" in order to earn higher financial returns as opposed to purposely funding low return loans as a form of "charity." In this section, we explore the extent to which our results on social networks can be attributed to altruism or mistakes that lenders eventually learn from.

First we look generally at how lenders change their behavior in response to previous social loans in their portfolio missing payments. Then we consider that lenders may have an even stronger charity motive within their own social networks by testing if lenders are less responsive to the payment history of own-group borrowers. Sociologists have argued that network members may do favors for each other, because the giver enjoys non-financial returns from the giving process such as approval of status within the network, future benefits from the network as a whole, or satisfaction of helping people within the same network (Portes 1998).

To test for learning we estimate a series of regressions describing how lender $i$ 's choices to fund, amount to fund, and type of loans to fund in week $t$ respond to 
characteristics and payment history of the lender's portfolio up through week $t-1$ :

(6) FundedALoan $_{i t}=g_{1}\left(\right.$ PortChar $_{i t-1}$, SocialLate $\left.i t-1\right)+a_{1 i t}+\mu_{1 i}+\gamma_{1 t}+\epsilon_{1 i t}$

(7)AmountFunded At $_{i t}=g_{2}\left(\right.$ PortChar $_{i t-1}$ SocialLate $\left._{i t-1}\right)+a_{2 i t}+\mu_{2 i}+\gamma_{2 t}+\epsilon_{2 i t}$

$$
\begin{aligned}
\text { AvgIRR }_{i t} & =g_{3}\left(\text { PortChar }_{i t-1}, \text { SocialLate }_{i t-1}\right)+a_{3 i t}+\mu_{3 i}+\gamma_{3 t}+\epsilon_{3 i t} \\
\text { PortComp }_{i t} & =g_{4}\left(\text { PortChar }_{i t-1}, \text { SocialLate }_{i t-1}\right)+a_{4 i t}+\mu_{4 i}+\gamma_{4 t}+\epsilon_{4 i t}
\end{aligned}
$$

Equation 6 is a linear probability model of an indicator that a lender funded at least one loan in a given week. ${ }^{26}$ The other three equations only include the sample of lenders who funded at least one loan in week $t$. In Equations 7 and 8, AmountFunded $_{i t}$ is the dollar amount invested by an active lender in week $t$, and $\operatorname{AvgIRR}_{i t}$ is the average IRR of the new loans that lender $i$ invests in during week $t$. Equation 9 is run separately for various measures of portfolio composition $\left(\right.$ PortComp $\left._{i t}\right)$, which specify the percentage of an active lender's investment in loans with certain social variables in week $t$. For example, in one set of regression, we look at the percentage of a week's investment that are in loans with or without friend endorsement and bids. In another set of regression, we look at the percentage of a week's investment in group or non-group loans. We recognize that the decision to fund loans and the amount of money invested in the market could be driven by both learning about the market and by liquidity constraints. However, we argue that changes in the types of loans lenders choose, conditional on continuing to lend, identify learning patterns.

On the right hand side of these regressions, we use SocialLate $_{i t-1}$ to describe corresponding social loan payment history as of the previous week, such as the fraction of previously funded endorsed loans in lender $i$ 's portfolio that have ever been late, fraction of previously funded group loans that have ever been late, etc. All regressions include lender fixed effects, thus our identification of the coefficients of the past loan performance variables is driven by within lender deviations from the mean of these variables. Therefore, there is likely to be a mechanical correlation between current loan characteristics and these deviations since the current loans affect the portfolio's mean percent late. To avoid this, all measures of portfolio percent late variables are calculated based solely on the payment histories of loans initiated in the lender's first month on Prosper, and the regressions consider lending decisions that occur after this first month. PortChar ${ }_{i t-1}$ includes lender $i$ 's portfolio HHI and portfolio size

\footnotetext{
${ }^{26}$ Because we will use a large number of fixed effects, we choose a linear probability model over a probit model for this set of regressions.
} 
through the previous week to control for time varying lender characteristics.

In addition to lender fixed effects, all regressions include year-week and lender age fixed effects. Year-week fixed effects $\left(\gamma_{j t}\right)$ control for changes in the macroeconomic environment and the Prosper market. ${ }^{27}$ Monthly lender age fixed effects $\left(a_{j i t}\right)$ capture any general pattern in lenders' choices as they age. ${ }^{28}$

Regression results are reported in Table 8. When previous loans of most types become late, lenders are less likely to fund new loans and invest less when they do fund new loans. Lenders also show expected substitution patterns between loans with friend endorsement without bids, friend endorsements with bids, and no friend endorsements (Panel A), and between group and non-group loans (Panel B). When one type of social loan becomes late, lenders shy away from new listings with the same social characteristic. Interestingly, the only loan type that does not follow this pattern is friend endorsement with a bid. We do not find any lender response to late loans of this type, which may be due to the fact that these loans generally repay at high rates and represent a small subset of loans. The overall effect of these substitution patterns is to find new loans with higher returns. This reaction suggests that charity is not the only motivation for funding social loans and lenders attempt to increase their profits in response to discovering poor outcomes for these types of loans.

It may be the case that charity lending is more likely to occur if lenders and borrowers belong to the same network. To check this, we run versions of Specifications (6)-(9) to test whether group lenders also substitute away from own-group loans when they observe late own-group loans in their portfolios. As reported in Panel $\mathrm{C}$ of Table 8, lenders who belong to groups fund less own-group loans when previous own-group loans in their portfolios have been late. This suggests within group charity is not a major driver of lenders funding group loans with poor outcomes.

\subsection{Do Lenders Share Information Within Social Networks?}

To this point we have mainly focused on social networks of the borrowers. While social networks on Prosper do not appear to generally provide valuable information about borrowers, it is possible that they provide other roles. In particular, lenders may utilize social networks to share information with each other. Our data is less

\footnotetext{
${ }^{27}$ Results of identical regressions with controls for macro variables and Prosper supply, demand, and market percent late instead of week fixed effects are very similar.

${ }^{28} \mathrm{We}$ count a lender as joining Prosper when he funds his first loan, and age is defined as months since joining Prosper. We cannot separately identify weekly age effects with both lender fixed effects and weekly time fixed effects.
} 
well suited to test the role of information transmission within networks, but we can test whether lender behavior is a function of the payment history of the loans funded by other lenders within the same group.

To test this, for lender $i$ at week $t$ we calculate the percent late for all the loans funded by his group up to week $t-1$ and add this GroupLate $_{g, t-1}$ variable on the right hand side of the learning regressions, with results presented in Panel A of Table 9. As with our previous results, the own-portfolio percent late has a significantly negative effect on the likelihood of funding future loans and the amount funded, and it has a significant positive effect on the IRR of funded loans. Interestingly, the coefficient on group-portfolio percent late is also negative and statistically significant in the funding regression and positive and statistically significant in the IRR regression. In fact, the group-portfolio coefficients are larger than the own-portfolio coefficients. This result suggests that an average group lender does learn from the outcomes of loans funded by other members of his group.

As a further test we restrict the sample to lenders in groups that have identifiable ties, such as alumni groups, military groups, and other connections defined in Table 3. These groups with stronger connections may be the most likely to share information within the group. We find that lenders in these groups with identifiable ties do learn even more strongly from their group portfolios, but only on the extensive margin of whether to fund loans on Prosper.

\section{Conclusion}

The growth of social networking on the Internet has opened opportunities to reduce information asymmetry between anonymous traders. However, online networking does not always imply legal links or social connections off the Internet, casting doubt on its value. Transaction data from Prosper.com suggests that social networking has some value, but is far from a perfect device for conveying information.

In particular, we find that borrowers with social ties are more likely to be funded and receive lower interest rates, conditional on other observed characteristics. This implies that lenders interpret these social ties as positive information about borrower quality. However, some social ties are not associated with better ex post loan outcomes. Our evidence on group heterogeneity, the effects of potentially perverse incentives, and lender learning suggest that this disconnect between lender funding behavior and borrower repayment rates is driven by lenders having difficulty understanding the information content of various social ties.

Our findings have a number of implications for the use of social networks in in- 
ternet commerce. First, our finding that the most positive form of social ties on Prosper is friend endorsement with accompanying bid suggests that social networks with some form of financial stake can play a role in conveying quality information. Second, our finding that members of smaller groups and groups with tangible ties deliver better loan outcomes suggests that some online networks can provide valuable screening and monitoring; however, the fact that Prosper lenders do not recognize these patterns suggests the importance of information transparency about the characteristics of social networks. Our results on gaming suggest that platforms interested in using social ties as a signal of quality would benefit from adopting policies that strengthen the information content of social ties, such as verification of social ties, safeguards against potential gaming, and better dissemination of information about social networks. It is also worth noting that platforms may face tradeoffs between short term growth and long run stability when designing policies that utilize social networks, especially when the platform's financial returns are more directly related to the volume of transactions rather than to the quality of transactions in the short run.

\section{References}

Agrawal, Ajay K.; Christian Catalini and Avi Goldfarb (2011) "The Geography of Crowdfunding" NBER Working Paper \#16820.

Ahlin, Christian (2009): "Matching for credit: Risk diversification in Thai microcredit groups" Michigan State University Working Paper.

Armendariz de Aghion, B. and J. Morduch (2010) The Economics of Microfinance, second edition. MIT press.

Arnott, Richard and Joseph E. Stiglitz (1991) "Moral Hazard and Nonmarket Institutions: Dysfunctional Crowding Out or Peer Monitoring?" The American Economic Review March 1991, 179-190.

Besley, Timothy and Stephen Coate (1995) "Group Lending, Repayment Incentives and Social Collateral" Journal of Development Economics Vol. 46, 1-18.

Bryan, Gharad; Dean Karlan and Jonathan Zinman (2010): "You Can Pick Your Friends, But You Need to Watch Them: Loan Screening and Enforcement in a Referrals Field Experiment" Working Paper 2010. 
Dellarocas, Chrysanthos (2003): "The Digitization of Word-of-Mouth: Promise and Challenges of Online Reputation Systems". Management Science 49 (10), October 2003, 1407-1424.

Duarte, Jefferson; Stephan Siegel and Lance Young (2012): "Trust and Credit: The Role of Appearance in Peer-to-Peer Lending" Review of Financial Studies, 25(8): 2455-2484.

Ellison, Glenn and Sara Fisher Ellison (2013): "Search, Obfuscation, and Price Elasticities on the Internet" Econometrica, 77(2): 427-452.

Feigenberg, Benjamin; Erica Field and Rohini Pande (2010) "Building Social Capital through Microfinance" NBER Working Paper \#16018.

Freedman, Seth and Ginger Z. Jin (2010) "Learning by Doing with Asymmetric Information: Evidence from Prosper.com" NBER Working Paper \#16855.

Gine, Xavier and Dean S. Karlan (2010) "Group versus Individual Liability: Long Term Evidence from Philippine Microcredit Lending Groups" Working Paper.

Gomez, Rafael and Eric Santor (2003) "Do peer group members outperform individual borrowers? A test of peer group lending using Canadian micro-credit data" Bank of Canada Working Paper 2003-33, October.

Greenlaw, David; Jan Hatzius; Anil Kashyap, Hyun Song Shin (2008) : "Leveraged Losses: Lessons from the Mortgage Market Meltdown", mimeo, accessed at http://www.chicagogsb.edu/usmpf/docs/usmpf2008confdraft.pdf.

Hampshire, Robert (2008) "Group Reputation Effects in Peer-to-Peer Lending Markets: An Empirical Analysis from a Principle-Agent Perspective" mimeo.

Hildenbrand, Thomas; Manju Puri; Jorg Rocholl (2016) "Adverse Incentives in Crowdfunding" Management Science forthcoming.

Hoff, Karla and Joseph E. Stiglitz (1990) "Introduction: Imperfect Information and Rural Credit Markets - Puzzles and Policy Perspectives" The World Bank Economic Review 4(3): 235-250.

Iyer, Rajkamal; Asim Ijaz Khwaja; Erzo F. P. Luttmer; Kelly Shue (2015) "Screening Peers Softly: Inferring the Quality of Small Borrowers" Management Science forthcoming. 
Jin, Ginger Z. and Andrew Kato (2007) "Dividing Online and Offline: A Case Study" Review of Economic Studies 74(3): 981-1004.

Karlan, Dean (2005) "Using Experimental Economics to Measure Social Capital and Predict Real Financial Decisions" American Economic Review 95(5): 16881699.

Kawai, Kei; Ken Onishi and Kosuke Uetake (2013) "Signaling in Online Credit Markets", New York University Working Paper, accessed at https://files.nyu.edu/ kk2319/public/Signaling_Submit.pdf on January 3, 2014.

La Ferrara, Eliana (2003) "Kin Groups and Reciprocity: A Model of Credit Transactions in Ghaha" American Economic Review 93(5): 1730-1751.

Lewis, Gregory (2011) "Asymmetric Information, Adverse Selection and Online Disclosure: The Case of eBay Motors", forthcoming American Economic Review.

Lin, Mingfeng; Siva Viswanathan and N.R. Prabhala (2013) "Judging Borrowers By The Company They Keep: Social Networks and Adverse Selection in Online Peer-to-Peer Lending" Management Science 59(1): 17-35.

Mendelson, Haim (2006) "Prosper.com: A People-to-People Lending Marketplace" mimeo.

Miller, Sarah (2015) "Information and Default in Consumer Credit Markets: Evidence from a Natural Experiment," Journal of Financial Intermediation 24(1): 45-70.

Morduch, Jonathan (1999) "The Microfinance Promise," Journal of Economic Literature Vol. XXXVII (December 1999), pp. 1569-1614.

Paravisini, Daniel; Veronica Rappoport and Enrichetta Ravina (2011) "Risk Aversion and Wealth: Evidence from Person-to-Person Lending Portfolios" mimeo.

Pope, Devin and Justin R. Sydnor (2011) "What's in a Picture? Evidence of Discrimination from Prosper.com" Journal of Human Resources 46(1): 53-92.

Portes, Alejandro (1998) "Social Capital: Its Origins and Applications in Modern Sociology" Annual Reviews of Sociology 24: 1-24. 
Ravina, Enrichetta (2007) "Love \& Loans: The Effect of Beauty and Personal Characteristics in Credit Markets," Available at SSRN: http://ssrn.com/abstract $=972801$.

Rigbi, Oren (2011) "The Effects of Usury Laws: Evidence from the Online Loan Market," Working Paper.

Rochet, Jean-Charles and Jean Tirole (2006) "Two-Sided Markets: A Progress Report" The RAND Journal of Economics Vol. 37, No. 3 (Autumn, 2006), pp. 645-667

Rysman, Marc (2009) "The Economics of Two-Sided Markets" Journal of Economics Perspectives, Vol. 23, No. 3, Summer 2009, pp. 125-43.

Stiglitz, Joseph E. (1990) "Peer Monitoring and Credit Markets" The World Bank Economic Review 4:3 351-366.

Stiglitz, Joseph E. and Andrew Weiss (1981): "Credit Rationing in Markets with Imperfect Information" American Economic Review 71(3): 393-410.

Tucker, Catherine (2011) "Social Networks, Personalized Advertising, and Privacy Controls," NET Institute Working Paper No. 10-07; MIT Sloan Research Paper No. 4851-10. Available at SSRN: http://ssrn.com/abstract=1694319

Tucker, Catherine (2012) "Social Advertising," Available at SSRN: http://ssrn.com/abstract $=1975897$

Udry, Cristopher (1994) "Risk and Insurance in a Rural Credit Market: An Empirical Investigation in Northern Nigeria" Review of Economic Studies 61(3): 495-526.

Wei, Yanhao, Pinar Yildirim, Christophe Van den Bulte, and Chrysanthos Dellarocas (2016) "Credit Scoring with Social Network Data" Marketing Science 35(2): $234-258$.

\section{Appendix: IRR Algorithm and Calculation}

This Appendix describes the data cleaning procedure before the IRR calculation, articulates the IRR algorithm, presents robustness checks of the IRR calculation, acknowledges our methodological limitation, and discusses the potential bias of the absolute measure of IRR. 
Data Cleaning: Our raw data were downloaded from Prosper.com as of August 18, 2011, which covers the full 36 months of loan age for all loans originated during our analysis sample between June 1, 2006 and July 31, 2011. Because of payment or administrative delays, some loans have performance data beyond month 36 . If the last available month of a loan presents a different performance status than month 36 , we replace the month 36 performance with the last month's performance. 1,145 loans ( $4.58 \%$ of all loans in our sample) have a terminal status "other," "origination delayed" or "repurchased." To avoid arbitrary interpretation of such codes, we exclude these 1,145 loans from the IRR calculation. For the remaining 23,863 loans, we always define payoff and misperformance as two absorbing states. If a loan's terminal status is "current," "paid," or "pay in progress," it is counted as fully paid at the end of the loan life. If a loan's status is "paid" prior to the last month, the loan is considered paid early and enters the payoff state. For misperformance, we consider three versions separately: default, misspay, and default or late. Default is the most conservative dummy variable of misperformance, which takes the value of one beginning the first month that a loan obtains a status of default. In the raw data, a loan is labeled default if the loan has been more than 3 months late. Misspay ignores lateness that does not lead to default; if default eventually occurs, misspay takes the value of one beginning 3 months before a loan becomes default. Default or late is the most aggressive dummy of misperformance, which takes the value of one beginning the first month a loan is late or default. We calculate IRR for these three definitions of misperformance separately.

IRR Algorithm: Assuming payoff (including early payoff) and misperformance are two absorbing states, a loan's status at month $t$ can be payoff, misperformance or current. If the status is current before the 36 th month, it can remain current or enter either the payoff or misperformance state permanently in the next month. This nature of the events best fits a duration model. Because the duration model with competing risks and time-varying explanatory variables is not yet fully developed, we consulted Professor John Ham, who has done extensive research in duration models and suggests the following estimation procedure in our context. Specifically, we use the loan-month data until one of the absorbing outcome events occurs to estimate two separate probit regressions, one for payoff and one for misperformance. For loan $l$ in age $a$ at calendar month $t$, the two logistic regressions are:

$$
\begin{gathered}
1(\text { payof }))_{l a}^{*}=\alpha_{1 a}+\beta_{1} \cdot \text { ListingAttribute }_{l}+\gamma_{1} \cdot \text { macro }_{l t}+\epsilon_{1 l t} \\
1\left(\text { misperformance }_{l a}^{*}=\alpha_{2 a}+\beta_{2} \cdot \text { ListingAttributes }_{l}+\gamma_{2} \cdot \text { macro }_{l t}+\epsilon_{2 l t} .\right.
\end{gathered}
$$


These two regressions essentially estimate the hazard risk of a particular outcome in age $a$ conditional on the loan still being current last month. Once we identify the coefficients, we can predict the hazard risk of payoff and misperformance under real macro conditions (denoted as $\left.\left.\hat{h}(Y)\right|_{\text {realmacro }}\right)$ and macro variables as of June 1, 2006 (denoted as $\left.\left.\hat{h}(Y)\right|_{\text {fixedmacro }}\right)$. In theory, we can interact macro with ListingAttributes extensively; however, when we include the interaction of macro and credit grade categories, some interactions are either dropped out completely or carry a coefficient of very large magnitude with very large standard errors. This is because these interactions are driven by very few observations. To avoid misleading predictions of hazard risk, our final estimation does not include these interactions but we include extensive interactions of credit grade categories with major listing attributes so that $\left.\hat{h}(Y)\right|_{\text {realmacro }}$ closely tracks the average hazard risk of loan performance in the real data. ${ }^{29}$

From these predicted hazard risks, we can predict the cumulative risk of payoff, current, and misperformance:

$$
\hat{\operatorname{prob}}\left({\text { payof } \left.f_{l a}\right)}=\hat{h}\left(\text { payof }_{l a}\right) \cdot \prod_{t=1}^{a-1}\left(1-\hat{h}\left(\text { payof }_{l t}\right)-\hat{h}\left(\text { misperform }_{l t}\right)\right)\right.
$$

$\hat{\operatorname{prob}}\left(\right.$ misperform $\left._{l a}\right)=\hat{h}\left(\right.$ misperform $\left._{l a}\right) \cdot \prod_{t=1}^{a-1}\left(1-\hat{h}\left(\right.\right.$ payof $\left._{l t}\right)-\hat{h}\left(\right.$ misperform $\left.\left._{l t}\right)\right)$

$$
\hat{\operatorname{prob}}\left(\text { current }_{l a}\right)=1-\hat{h}\left({\text { payof } \left.f_{l a}\right)-\hat{h}\left(\text { misperform }_{l a}\right)}\right. \text {. }
$$

For loan $l, I R R_{l}$ is defined as the interest rate $r_{l}$ that equalizes the loan amount $\left(M_{l}\right)$ to the present value of expected cash flows from the 36 months of loan life:

$$
I R R_{l}=\underset{r_{l}}{\operatorname{argmin}}\left\{-M_{l}+\sum_{a=1}^{36}\left[\operatorname{cashflow}_{l a} /\left(1+r_{l}\right)^{a}\right]\right\}^{2}
$$

\footnotetext{
${ }^{29}$ We have estimated IRR with different degrees of macro Listing Attributes. The cross-sectional variations of these IRR estimates are qualitatively similar to the IRRs reported here, though the absolute magnitude of each IRR estimate usually change by one or a few percentage points.
} 
where the predicted cash flow is defined as:

$$
\operatorname{cashflow}_{l a}=\hat{\operatorname{prob}}\left(\operatorname{payof}_{l a}\right) \cdot M_{l a}^{\text {payoff }}+\hat{\operatorname{prob}}\left(\text { current }_{l a}\right) \cdot M_{l a}^{\text {current }}-\text { ProsperFee }_{l a}
$$

with $M_{l a}^{\text {payoff }}$ defined as the total amount the borrower owes if she pays off the loan in month $a, M_{l a}^{\text {current }}$ defined as the scheduled monthly payment when the loan is originated, and ProsperFee $e_{a}$ defined according to Prosper definition of lender fees. Because cash-flow per month cannot be negative by definition, each loan has a unique solution of $I R R_{l}$ for a given set of loan terms (principal, interest rate, loan time).

The above algorithm produces six versions of $I R R_{l}$, depending on whether we measure misperformance by default, misspay, or default or late, and whether we use real macro or macro variables fixed on June 1, 2006 to predict the hazard risk of payoff and misperformance. Appendix Table 2 summarizes these six versions of $I R R_{l}$ for all the 23,863 loans that we have enough information to compute loan status each month. The absolute magnitude of IRR varies in expected directions: measuring misperformance by default yields higher IRRs than measuring it by misspay, and measuring it by misspay produces higher IRRs than measuring it by default or late. Calculation under real macro leads to lower IRRs than fixed macro, except when we measure misperformance by default or late. This is probably because the macro changes since June 1, 2006 affect the risk of lateness and default differently. The main text of the paper reports results using IRR6 (default or late, fixed macro). We find similar results when we rerun all regressions using the fixed macro IRR when misperformance is measured in default (IRR2), and the real macro IRR when misperformance is measured by default or default or late (IRR1, IRR5). ${ }^{30}$

Potential bias and limitation The calculated IRR differs from raw performance data in several ways: first, it assumes that a sophisticated return-maximizing lender has rational expectation on the statistical relationship between observable macroeconomic or borrower attributes and ex post loan performance; second, it fixes lender expectation of the macroeconomic environment as of June 1, 2006 and therefore filters out unexpected macroeconomic shocks; third, it considers the timing of every payment outcome. For example a default that occurs in the first month is different from a default in the 36th month because lenders have earned almost all the principal and interests in the latter case. Similarly, an early payoff can imply a

\footnotetext{
${ }^{30}$ By definition, the only difference between misspay and default is misspay counting three more months of lateness in misperformance right before the month of default. So IRR3 is very similar to IRR1 and IRR4 is very similar to IRR2. This is why our robustness checks focus on the comparison of default versus default or late.
} 
lower IRR than a late default. This is because early payoff is counted as cash flow at the time of payoff, which in the IRR calculation implies that the payoff amount is reinvested in a similar loan subject to a new round of risk of default, payoff, etc. As such, the empirical results below on raw performance outcomes and IRR are not always the same, and this highlights the importance of considering all the possible outcomes every month and summarizing them in the IRR.

There are a couple of limitations in our algorithm: first, our IRR estimates are based on the average loan performance observed from June 1, 2006 to August 18, 2011, a period that stretches from the end of a boom to slow recovery out of an economy-wide recession. Our model of macro variables may be oversimplified. Second, we estimate the hazard risk of payoff and misperformance separately, assuming that unobservable factors affect the two hazards independently. This assumption can be strong in some situations.

No matter which version of IRR we use, the absolute magnitude of our IRR is subject to potential bias in both directions. On the one hand, our IRR estimates may be downward biased because we are conservative in the calculation of cash flows. Specifically, we treat misperformance as an absorbing state, which can be violated in rare cases (e.g. a late loan can become current, and a default loan can be eventually paid back). Even if a default loan remains default, we assume away any loss recovery from default loans, and we do not account for the late fees that a lender may receive from a late, but non-defaulting borrower. When we count early payoff as a bulk cash flow that arrives in the paid-off month, it effectively assumes that the paid off amount is reinvested in a loan that is identical to the loan under study. This assumption may be conservative because lenders may learn to fund better loans over time. On the other hand, our IRR estimates may have overestimated the return on investment because we do not consider any cost that lenders may incur in processing Prosper information. The time that lenders spend on screening listings and digesting Prosper history could be long and stressful.

This paper aims to detect the information value of social networking and therefore we focus on the relative magnitude of IRR across loans, rather than the absolute magnitude of IRR. 
Table 1: History of Prosper Policies during Data Period, July 1, 2006 - July 31, 2008

\begin{tabular}{ll}
\hline Always & $\begin{array}{l}\text { Listings include credit grade, some credit history (e.g. the number of delinquency), home ownership status, debt-to-income ratio } \\
\text { Members can join and create groups }\end{array}$ \\
\hline Oct. 19, 2006 & Began posting group star ratings based on past loan performance \\
\hline Feb. 12, 2007 & $\begin{array}{l}\text { Reveal more credit info (e.g. amount delinquent) } \\
\text { Allow friend endorsements }\end{array}$ \\
\hline Sept. 12, 2007 & Eliminate group leader rewards (\$12/new borrower) \\
\hline Oct. 30, 2007 & Add Prosper-estimated rate of return, labeled "bidder guidance" \\
\hline Feb. 23, 2008 & Allow borrowers to include friend bids and endorsements in listing search criteria \\
\hline
\end{tabular}

Notes: Changes to borrower information depicted in plain text. Changes to social network related policies depicted in italic text. 
Table 2: Summary of Listings and Loans by Quarter

\begin{tabular}{|c|c|c|c|c|c|c|c|c|c|c|}
\hline \multirow{2}{*}{$\begin{array}{c}\text { A: Listings } \\
\text { Quarter } \\
\end{array}$} & \multicolumn{2}{|c|}{ Total Market } & \multicolumn{3}{|c|}{ Mean Listing Characteristics } & \multicolumn{5}{|c|}{ Percent of Listings by Social Network Characteristics } \\
\hline & Number & $\begin{array}{c}\text { Amount } \\
\text { Requested } \\
(\$ 100,000)\end{array}$ & $\begin{array}{l}\text { Amount } \\
\text { Requested } \\
(\$) \\
\end{array}$ & $\begin{array}{c}\text { Borrower } \\
\text { Max Interest } \\
\text { Rate } \\
\end{array}$ & $\begin{array}{c}\text { Funding } \\
\text { rate }\end{array}$ & $\begin{array}{c}\text { In a } \\
\text { Group }\end{array}$ & $\begin{array}{c}\text { Group Leader } \\
\text { Endorsement } \\
\text { w/out Bid } \\
\end{array}$ & $\begin{array}{c}\text { Group Leader } \\
\text { Endorsement } \\
\text { w/ Bid }\end{array}$ & $\begin{array}{c}\text { Friend } \\
\text { Endorsement } \\
\text { w/out Bid } \\
\end{array}$ & $\begin{array}{c}\text { Friend } \\
\text { Endorsement } \\
\text { w/ Bid } \\
\end{array}$ \\
\hline 20062 & 5,375 & 26.65 & $4,957.22$ & $16.86 \%$ & $10.01 \%$ & $58.59 \%$ & $0.00 \%$ & $0.00 \%$ & $0.00 \%$ & $0.00 \%$ \\
\hline 20063 & 19,771 & 107.25 & $5,424.63$ & $18.15 \%$ & $9.94 \%$ & $61.84 \%$ & $0.42 \%$ & $0.71 \%$ & $0.00 \%$ & $0.00 \%$ \\
\hline 20064 & 31,629 & 196.57 & $6,214.85$ & $17.45 \%$ & $7.98 \%$ & $53.57 \%$ & $1.33 \%$ & $2.04 \%$ & $0.00 \%$ & $0.00 \%$ \\
\hline 20071 & 31,373 & 263.22 & $8,389.94$ & $16.72 \%$ & $10.14 \%$ & $48.24 \%$ & $1.42 \%$ & $3.46 \%$ & $11.04 \%$ & $0.58 \%$ \\
\hline 20072 & 37,505 & 331.62 & $8,841.98$ & $17.51 \%$ & $8.07 \%$ & $34.09 \%$ & $1.07 \%$ & $5.68 \%$ & $20.86 \%$ & $0.97 \%$ \\
\hline 20073 & 39,353 & 328.79 & $8,355.00$ & $18.06 \%$ & $6.71 \%$ & $23.64 \%$ & $1.01 \%$ & $4.10 \%$ & $19.93 \%$ & $1.14 \%$ \\
\hline 20074 & 41,585 & 334.23 & $8,037.29$ & $18.41 \%$ & $6.32 \%$ & $16.08 \%$ & $1.42 \%$ & $0.84 \%$ & $16.48 \%$ & $1.33 \%$ \\
\hline 20081 & 33,485 & 250.14 & $7,470.30$ & $19.24 \%$ & $9.46 \%$ & $12.77 \%$ & $0.70 \%$ & $0.75 \%$ & $12.91 \%$ & $1.86 \%$ \\
\hline 20082 & 43,371 & 318.53 & $7,344.20$ & $24.50 \%$ & $10.08 \%$ & $7.83 \%$ & $0.54 \%$ & $0.64 \%$ & $9.36 \%$ & $1.58 \%$ \\
\hline 20083 & 10,361 & 73.48 & $7,092.42$ & $26.40 \%$ & $9.31 \%$ & $7.53 \%$ & $0.53 \%$ & $0.61 \%$ & $8.98 \%$ & $1.89 \%$ \\
\hline Total & 293,808 & $2,230.48$ & $7,591.62$ & $19.19 \%$ & $8.51 \%$ & $28.82 \%$ & $0.98 \%$ & $2.23 \%$ & $12.01 \%$ & $1.04 \%$ \\
\hline \multirow[t]{2}{*}{ B: Loans } & \multicolumn{2}{|c|}{ Total Market } & \multicolumn{3}{|c|}{ Mean Loan Characteristics } & \multicolumn{5}{|c|}{ Percent of Loans by Social Network Characteristics } \\
\hline & Number & $\begin{array}{c}\text { Amount } \\
\text { Funded } \\
(\$ 100,000)\end{array}$ & $\begin{array}{l}\text { Amount } \\
\text { Funded } \\
(\$)\end{array}$ & $\begin{array}{c}\text { Contract } \\
\text { Interest Rate }\end{array}$ & $\begin{array}{c}\text { Default } \\
\text { Rate }\end{array}$ & $\begin{array}{c}\text { In a } \\
\text { Group }\end{array}$ & $\begin{array}{c}\text { Group Leader } \\
\text { Endorsement } \\
\text { w/out Bid }\end{array}$ & $\begin{array}{c}\text { Group Leader } \\
\text { Endorsement } \\
\text { w/ Bid }\end{array}$ & $\begin{array}{c}\text { Friend } \\
\text { Endorsement } \\
\text { w/out Bid }\end{array}$ & $\begin{array}{c}\text { Friend } \\
\text { Endorsement } \\
\text { w/ Bid }\end{array}$ \\
\hline 20062 & 385 & 1.47 & $3,822.17$ & $19.03 \%$ & $30.39 \%$ & $67.01 \%$ & $0.00 \%$ & $0.00 \%$ & $0.00 \%$ & $0.00 \%$ \\
\hline 20063 & 1,934 & 9.37 & $4,844.63$ & $19.41 \%$ & $28.54 \%$ & $71.30 \%$ & $1.14 \%$ & $3.10 \%$ & $0.00 \%$ & $0.00 \%$ \\
\hline 20064 & 2,403 & 11.54 & $4,804.05$ & $18.97 \%$ & $29.09 \%$ & $70.20 \%$ & $4.04 \%$ & $12.82 \%$ & $0.00 \%$ & $0.00 \%$ \\
\hline 20071 & 3,079 & 19.93 & $6,472.60$ & $17.37 \%$ & $23.74 \%$ & $67.49 \%$ & $4.38 \%$ & $17.93 \%$ & $10.91 \%$ & $2.24 \%$ \\
\hline 20072 & 3,118 & 23.47 & $7,527.98$ & $17.42 \%$ & $17.54 \%$ & $63.28 \%$ & $4.36 \%$ & $29.76 \%$ & $27.77 \%$ & $4.62 \%$ \\
\hline 20073 & 2,671 & 18.43 & $6,900.12$ & $17.31 \%$ & $9.21 \%$ & $44.85 \%$ & $4.64 \%$ & $23.40 \%$ & $26.21 \%$ & $5.13 \%$ \\
\hline 20074 & 2,593 & 18.98 & $7,320.17$ & $17.11 \%$ & $4.09 \%$ & $23.95 \%$ & $2.70 \%$ & $6.44 \%$ & $22.33 \%$ & $6.56 \%$ \\
\hline 20081 & 3,074 & 20.47 & $6,658.94$ & $17.37 \%$ & $0.46 \%$ & $19.00 \%$ & $0.81 \%$ & $3.81 \%$ & $17.99 \%$ & $5.50 \%$ \\
\hline 20082 & 4,344 & 26.33 & $6,061.10$ & $17.98 \%$ & $0.00 \%$ & $13.54 \%$ & $1.31 \%$ & $3.06 \%$ & $14.11 \%$ & $5.62 \%$ \\
\hline 20083 & 1,407 & 8.27 & $5,877.70$ & $19.39 \%$ & $0.00 \%$ & $10.80 \%$ & $0.78 \%$ & $2.70 \%$ & $12.30 \%$ & $6.54 \%$ \\
\hline Total & 25,008 & 158.27 & $6,328.65$ & $17.90 \%$ & $12.04 \%$ & $42.06 \%$ & $2.71 \%$ & $11.71 \%$ & $15.28 \%$ & $4.10 \%$ \\
\hline
\end{tabular}

Notes: Authors' tabulations from Prosper listing and loan data. Funding rate refers to the percentage of listings that become funded loans. The sample includes all the listings and loans between June 1, 2006 and July 31, 2008. 


\section{Table 3: Summary Statistics of Social Network Variables}

\begin{tabular}{|c|c|c|c|c|c|c|}
\hline & \multicolumn{3}{|c|}{ Listings } & \multicolumn{3}{|c|}{ Loans } \\
\hline & Mean & $\mathrm{SD}$ & $\mathrm{N}$ & Mean & SD & $\mathrm{N}$ \\
\hline$\%$ In a Group & 0.288 & 0.453 & 293,808 & 0.421 & 0.494 & 25,008 \\
\hline$\%$ with Friends & 0.191 & 0.393 & 293,808 & 0.249 & 0.432 & 25,008 \\
\hline \% w/ Group Leader Endorsement no Bid & 0.010 & 0.098 & 293,808 & 0.027 & 0.162 & 25,008 \\
\hline$\%$ w/ Group Leader Endorsement + Bid & 0.022 & 0.148 & 293,808 & 0.117 & 0.322 & 25,008 \\
\hline$\%$ w/ Friend Endorsement no Bid & 0.120 & 0.325 & 293,808 & 0.153 & 0.360 & 25,008 \\
\hline$\% \mathrm{w} /$ Friend Endorsement + Bid & 0.010 & 0.101 & 293,808 & 0.041 & 0.198 & 25,008 \\
\hline \multicolumn{7}{|l|}{ Conditional on a borrower in a group: } \\
\hline Number of Members & 1799.214 & 2346.502 & 84,377 & 1176.963 & 1872.194 & 10,512 \\
\hline Number of Borrowers & 1082.372 & 1311.981 & 84,377 & 724.992 & 1070.800 & 10,512 \\
\hline Number of Lenders & 198.860 & 248.414 & 84,377 & 159.373 & 217.842 & 10,512 \\
\hline 1-100 Borrowers & 0.232 & 0.422 & 84,680 & 0.308 & 0.462 & 10,518 \\
\hline 101-500 Borrowers & 0.225 & 0.418 & 84,680 & 0.296 & 0.457 & 10,518 \\
\hline 501-1000 Borrowers & 0.251 & 0.434 & 84,680 & 0.209 & 0.406 & 10,518 \\
\hline$>1001$ Borrowers & 0.288 & 0.453 & 84,680 & 0.186 & 0.389 & 10,518 \\
\hline$\%$ of Members that are Borrowers & 0.627 & 0.153 & 84,377 & 0.651 & 0.166 & 10,512 \\
\hline Alumni Group & 0.023 & 0.148 & 84,680 & 0.029 & 0.168 & 10,518 \\
\hline Military Group & 0.019 & 0.137 & 84,680 & 0.014 & 0.119 & 10,518 \\
\hline $\begin{array}{l}\text { Other Connections (Employment, Local, } \\
\text { Personal) }\end{array}$ & 0.017 & 0.128 & 84,680 & 0.022 & 0.145 & 10,518 \\
\hline $\begin{array}{l}\text { Loose Connection (Common Religion or } \\
\text { Ethnicity) }\end{array}$ & & & & & & \\
\hline $\begin{array}{l}\text { Ethnicity) } \\
\text { Listing Review Required }\end{array}$ & $\begin{array}{l}0.025 \\
0.341\end{array}$ & $\begin{array}{l}0.156 \\
0.474\end{array}$ & $\begin{array}{l}84,680 \\
84,680\end{array}$ & $\begin{array}{l}0.016 \\
0.519\end{array}$ & $\begin{array}{l}0.125 \\
0.500\end{array}$ & $\begin{array}{l}10,518 \\
10,518\end{array}$ \\
\hline \% Funded by Group Members & & & & 0.017 & 0.062 & 10,518 \\
\hline$\%$ Funded by Group Leader & & & & 0.032 & 0.124 & 10,518 \\
\hline \multicolumn{7}{|c|}{ Conditional on a borrower in a group \& after $10 / 19 / 06:$} \\
\hline Low Rated Group & 0.414 & 0.493 & 66,062 & 0.275 & 0.447 & 8,416 \\
\hline High Rated Group & 0.323 & 0.468 & 66,062 & 0.421 & 0.494 & 8,416 \\
\hline Nonrated Group & 0.261 & 0.439 & 66,062 & 0.301 & 0.459 & 8,416 \\
\hline \multicolumn{7}{|c|}{ Conditional on a borrower that has friends: } \\
\hline$\%$ Funded by Friends & & & & 0.033 & 0.143 & 6,229 \\
\hline \multicolumn{7}{|c|}{ Conditional on a borrower that has endorsement(s): } \\
\hline$\%$ Funded by Endorsing Friends & & & & 0.027 & 0.126 & 4,845 \\
\hline$\%$ Funded by Endorsing Group Leader & & & & 0.055 & 0.150 & 3,605 \\
\hline
\end{tabular}

Notes: Authors' tabulations from Prosper listing and loan data. The sample includes all the listings and loans between June 1, 2006 and July 31, 2008. 
Table 4: Summary of Listing and Loan Characteristics and Outcomes by Social Network Variables

\begin{tabular}{|c|c|c|c|c|c|c|c|c|}
\hline & $\begin{array}{c}\text { Grade E or } \\
\text { Lower } \\
\text { Listing } \\
\end{array}$ & $\begin{array}{c}\text { Grade E or } \\
\text { Lower } \\
\text { Loans } \\
\end{array}$ & $\begin{array}{c}\text { Funding } \\
\text { Rate }\end{array}$ & $\begin{array}{c}\text { Contract } \\
\text { Rate }\end{array}$ & $\begin{array}{c}\text { Default or } \\
\text { Late }\end{array}$ & Paid Off & N Listings & N Loans \\
\hline Not in a group & 0.595 & 0.156 & 0.069 & 0.175 & 0.205 & 0.198 & 209,128 & 14,490 \\
\hline In a Group & 0.680 & 0.363 & 0.124 & 0.185 & 0.266 & 0.175 & 84,680 & 10,518 \\
\hline Group Leader Endorsement \& No Bid & 0.495 & 0.230 & 0.236 & 0.176 & 0.246 & 0.171 & 2,865 & 677 \\
\hline Group Leader Endorsement \& Bid & 0.482 & 0.357 & 0.447 & 0.179 & 0.278 & 0.147 & 6,555 & 2,928 \\
\hline Friend Endorsement \& No Bid & 0.585 & 0.245 & 0.108 & 0.188 & 0.262 & 0.160 & 35,294 & 3,820 \\
\hline Friend Endorsement \& Bid & 0.343 & 0.217 & 0.336 & 0.163 & 0.158 & 0.202 & 3,047 & 1,025 \\
\hline
\end{tabular}

Notes: Authors' tabulations from Prosper listing and loan data. The sample includes all the listings and loans between June 1, 2006 and July 31,2008 


\section{Table 5: Effects of Basic Social Variables}

\begin{tabular}{|c|c|c|c|c|c|}
\hline & I(Funded) & $\begin{array}{c}\text { Contract } \\
\text { Interest Rate }\end{array}$ & I(Default or Late) & I(Paid Off) & IRR \\
\hline & Probit (marg. eff.) & OLS & Probit (marg. eff.) & Probit (marg. eff.) & OLS \\
\hline In a Group & $\begin{array}{r}0.002 * * * \\
(0.0002)\end{array}$ & $\begin{array}{c}-0.004 * * * \\
(0.0004)\end{array}$ & $\begin{array}{c}0.006^{* * *} \\
(0.001)\end{array}$ & $\begin{array}{c}-0.004 * * * \\
(0.001)\end{array}$ & $\begin{array}{c}-0.018 * * * \\
(0.001)\end{array}$ \\
\hline Group Leader Endorsement \& No Bid & $\begin{array}{c}0.010 * * * \\
(0.001)\end{array}$ & $\begin{array}{c}-0.003 * * \\
(0.001)\end{array}$ & $\begin{array}{l}-0.001 \\
(0.002)\end{array}$ & $\begin{array}{c}-0.028 * * * \\
(0.002)\end{array}$ & $\begin{array}{c}0.019 * * * \\
(0.002)\end{array}$ \\
\hline Group Leader Endorsement \& Bid & $\begin{array}{c}0.062 * * * \\
(0.004)\end{array}$ & $\begin{array}{c}-0.004 * * * \\
(0.001)\end{array}$ & $\begin{array}{c}0.007 * * * \\
(0.001)\end{array}$ & $\begin{array}{c}-0.029 * * * \\
(0.001)\end{array}$ & $\begin{array}{c}-0.013 * * * \\
(0.001)\end{array}$ \\
\hline Friend Endorsement \& No Bid & $\begin{array}{l}0.001 * * * \\
(0.0002)\end{array}$ & $\begin{array}{l}0.001 * * \\
(0.001)\end{array}$ & $\begin{array}{c}0.004 * * * \\
(0.001)\end{array}$ & $\begin{array}{c}-0.012 * * * \\
(0.001)\end{array}$ & $\begin{array}{c}-0.008 * * * \\
(0.001)\end{array}$ \\
\hline Friend Endorsement \& Bid & $\begin{array}{c}0.034 * * * \\
(0.004)\end{array}$ & $\begin{array}{c}-0.006^{* * *} \\
(0.001)\end{array}$ & $\begin{array}{c}-0.041 * * * \\
(0.002)\end{array}$ & $\begin{array}{c}0.006^{* * *} \\
(0.002)\end{array}$ & $\begin{array}{c}0.060 * * * \\
(0.002)\end{array}$ \\
\hline $\mathrm{N}$ & 293,800 & 23,863 & 859,068 & 858,960 & 23,863 \\
\hline Year-week FE & $\mathrm{X}$ & $\mathrm{X}$ & $\mathrm{X}$ & $\mathrm{X}$ & $\mathrm{X}$ \\
\hline Loan-age FE & & & $\mathrm{X}$ & $\mathrm{X}$ & \\
\hline Contract Rate Control & & & $\mathrm{X}$ & $\mathrm{X}$ & \\
\hline
\end{tabular}


Table 6: Group Characteristics Conditional on Group Member Listing

\begin{tabular}{|c|c|c|c|c|}
\hline & I(Funded) & Contract Interest Rate & I(Default or Late) & IRR \\
\hline & Probit (marg. eff.) & OLS & Probit (marg. eff.) & OLS \\
\hline \multicolumn{5}{|l|}{ Ratings } \\
\hline Not Rated (After Ratings Available) & $\begin{array}{c}-0.008^{* *} \\
(0.004)\end{array}$ & $\begin{array}{l}-0.001 \\
(0.005)\end{array}$ & $\begin{array}{l}0.021^{*} \\
(0.013)\end{array}$ & $\begin{array}{l}-0.016 \\
(0.010)\end{array}$ \\
\hline Low Rating (1-3 stars) & $\begin{array}{l}-0.008^{*} \\
(0.005)\end{array}$ & $\begin{array}{c}0.003 \\
(0.005)\end{array}$ & $\begin{array}{l}-0.001 \\
(0.012)\end{array}$ & $\begin{array}{c}0.044 * * * \\
(0.010)\end{array}$ \\
\hline High Rating (4-5 stars) & $\begin{array}{l}-0.003 \\
(0.005)\end{array}$ & $\begin{array}{l}0.000 \\
(0.005)\end{array}$ & $\begin{array}{c}0.003 \\
(0.012)\end{array}$ & $\begin{array}{c}0.026^{* * *} \\
(0.010)\end{array}$ \\
\hline \multicolumn{5}{|l|}{ Size and Composition } \\
\hline $1-100$ borrowers & $\begin{array}{l}0.009 * * * \\
(0.001)\end{array}$ & $\begin{array}{c}-0.004 * * * \\
(0.001)\end{array}$ & $\begin{array}{c}-0.020 * * * \\
(0.003)\end{array}$ & $\begin{array}{c}0.034 * * * \\
(0.002)\end{array}$ \\
\hline 101-500 borrowers & $\begin{array}{c}0.005^{* * * *} \\
(0.001)\end{array}$ & $\begin{array}{c}-0.005 * * * \\
(0.001)\end{array}$ & $\begin{array}{l}-0.003 \\
(0.002)\end{array}$ & $\begin{array}{c}-0.009 * * * \\
(0.001)\end{array}$ \\
\hline $501-1000$ borrowers & $\begin{array}{c}-0.002 * * \\
(0.001)\end{array}$ & $\begin{array}{c}-0.003^{* * *} \\
(0.001)\end{array}$ & $\begin{array}{c}-0.006 * * * \\
(0.002)\end{array}$ & $\begin{array}{c}-0.003^{* *} \\
(0.001)\end{array}$ \\
\hline$\%$ of borrowers $<25 \%$ & $\begin{array}{c}-0.007 * * * \\
(0.002)\end{array}$ & $\begin{array}{c}0.003 \\
(0.002)\end{array}$ & $\begin{array}{c}-0.088^{* * *} \\
(0.010)\end{array}$ & $\begin{array}{c}0.102 * * * \\
(0.006)\end{array}$ \\
\hline$\%$ of borrowers betw $25 \%$ and $50 \%$ & $\begin{array}{c}0.000 \\
(0.001)\end{array}$ & $\begin{array}{c}0.001 \\
(0.001)\end{array}$ & $\begin{array}{c}-0.043^{* * *} \\
(0.004)\end{array}$ & $\begin{array}{l}0.045 * * * \\
(0.002)\end{array}$ \\
\hline$\%$ of borrowers betw $50 \%$ and $75 \%$ & $\begin{array}{l}0.002 * * * \\
(0.001)\end{array}$ & $\begin{array}{l}0.001 * \\
(0.001)\end{array}$ & $\begin{array}{c}-0.024 * * * \\
(0.003)\end{array}$ & $\begin{array}{c}0.012 * * * \\
(0.001)\end{array}$ \\
\hline \multicolumn{5}{|l|}{ Туре } \\
\hline Alumni & $\begin{array}{c}0.003 \\
(0.002)\end{array}$ & $\begin{array}{c}0.002 \\
(0.001)\end{array}$ & $\begin{array}{c}-0.037 * * * \\
(0.005)\end{array}$ & $\begin{array}{c}0.031 * * * \\
(0.004)\end{array}$ \\
\hline $\begin{array}{l}\text { Other Connections } \\
\text { (Employment, Local, Personal) }\end{array}$ & $\begin{array}{l}0.000 \\
(0.002)\end{array}$ & $\begin{array}{c}0.001 \\
(0.001)\end{array}$ & $\begin{array}{c}-0.047 * * * \\
(0.006)\end{array}$ & $\begin{array}{c}0.039 * * * \\
(0.003)\end{array}$ \\
\hline $\begin{array}{l}\text { Loose Connection } \\
\text { (Common Religion or Ethnicity) }\end{array}$ & $\begin{array}{l}-0.003 \\
(0.002)\end{array}$ & $\begin{array}{c}-0.005^{* *} \\
(0.002)\end{array}$ & $\begin{array}{l}-0.007 \\
(0.005)\end{array}$ & $\begin{array}{c}0.026^{* * *} \\
(0.004)\end{array}$ \\
\hline Military & $\begin{array}{c}-0.007 * * * \\
(0.002)\end{array}$ & $\begin{array}{c}0.001 \\
(0.002)\end{array}$ & $\begin{array}{c}0.014 * * \\
(0.006)\end{array}$ & $\begin{array}{c}-0.035^{* * * *} \\
(0.004)\end{array}$ \\
\hline \multicolumn{5}{|l|}{ Leader Review } \\
\hline Group Leader Review Requirement & $\begin{array}{c}0.005 * * * \\
(0.001)\end{array}$ & $\begin{array}{c}0.002 * * \\
(0.001)\end{array}$ & $\begin{array}{c}-0.004 * * * \\
(0.002)\end{array}$ & $\begin{array}{l}-0.000 \\
(0.001)\end{array}$ \\
\hline $\mathrm{N}$ & 84,676 & 10,015 & 360,036 & 10,015 \\
\hline Year-week FE & X & $\mathrm{X}$ & $\mathrm{X}$ & $\mathrm{X}$ \\
\hline Loan-age FE & & & $\mathrm{X}$ & \\
\hline Contract Rate Control & & & $\mathrm{X}$ & \\
\hline
\end{tabular}

Notes: The sample includes all the listings and loans between June 1, 2006 and July 31, 2008. Robust standard errors are in parenthesis. ${ }^{* * *} \mathrm{p}<0.01,{ }^{* *} \mathrm{p}<0.05,{ }^{*} \mathrm{p}<0.1$. Columns 1 includes all listings while all other columns include only completed loans for which we observe final loan performance status. Columns 1,2, and 4 are at the listing/loan level, and Column 3 is at the loanmonth level. All regressions control for state dummies, year-week FE, macro variables (except for the IRR regression), duration of auction, and posted credit attributes. Column 3 also control for monthly loan age fixed effects and the loan's contract interest rate. Variables for group and friend endorsements are also included in this regression, but excluded from the table to save space. The coefficient estimates on these variables are similar to those in previous tables. 
Table 7: Potential Gaming

\begin{tabular}{lcccc}
\hline & I(Funded) & $\begin{array}{c}\text { Contract } \\
\text { Interest Rate }\end{array}$ & I(Default or Late) & IRR \\
\cline { 2 - 4 } & Probit (marg. eff.) & OLS & Probit (marg. eff.) & OLS \\
\hline Basic Social Variables & & & & \\
In a Group & $0.002^{*}$ & $-0.005^{*}$ & $0.019^{*}$ & $-0.023^{*}$ \\
& $(0.000)$ & $(0.000)$ & $(0.001)$ & $(0.001)$ \\
Group Leader Endorsement \& No Bid & $0.013^{*}$ & -0.001 & $-0.013^{*}$ & $0.021^{*}$ \\
Group Leader Endorsement \& Bid & $(0.002)$ & $(0.001)$ & $(0.002)$ & $(0.003)$ \\
& $0.062^{*}$ & $-0.003^{*}$ & $0.006^{*}$ & $-0.012^{*}$ \\
Friend Endorsement \& No Bid & $(0.004)$ & $(0.001)$ & $(0.001)$ & $(0.001)$ \\
& $0.001^{*}$ & $0.001^{* *}$ & $0.005^{*}$ & $-0.008^{*}$ \\
Friend Endorsement \& Bid & $(0.000)$ & $(0.001)$ & $(0.001)$ & $(0.001)$ \\
Gaming & $0.032^{*}$ & $-0.006^{*}$ & $-0.036^{*}$ & $0.061^{*}$ \\
In a Group after Leader Rewards Removed & $(0.004)$ & $(0.001)$ & $(0.002)$ & $(0.002)$ \\
& & & & \\
Group Leader Endorsement \& No Bid & -0.000 & $0.004^{*}$ & $-0.032^{*}$ & $0.013^{*}$ \\
$\quad$ After Leader Rewards Removed & $(0.000)$ & $(0.001)$ & $(0.002)$ & $(0.002)$ \\
Group Leader Endorsement \& Bid & $-0.002^{*}$ & $-0.008^{*}$ & $0.058^{*}$ & $-0.010^{* *}$ \\
$\quad$ After Leader Rewards Removed & $(0.001)$ & $(0.003)$ & $(0.007)$ & $(0.004)$ \\
Mutual Friend Endorsement \& No Bid & -0.000 & $-0.006^{*}$ & -0.004 & 0.000 \\
& $(0.001)$ & $(0.002)$ & $(0.003)$ & $(0.003)$ \\
Mutual Friend Endorsement \& Bid & $0.002^{*}$ & -0.001 & -0.001 & -0.001 \\
& $(0.001)$ & $(0.001)$ & $(0.002)$ & $(0.002)$ \\
N & 0.001 & -0.003 & $-0.065^{*}$ & $-0.012^{* * *}$ \\
Year-week FE & $(0.002)$ & $(0.005)$ & $(0.006)$ & $(0.007)$ \\
Loan-age FE & & & & 23,863 \\
Contract Rate Control & 293,800 & 23,863 & 859,068 & $\mathrm{X}$ \\
\hline Nots: The & $\mathrm{X}$ & $\mathrm{X}$ & $\mathrm{X}$ & \\
\hline
\end{tabular}

Notes: The sample includes all the listings and loans between June 1, 2006 and July 31, 2008. Robust standard errors are in parenthesis. ${ }^{* * *} \mathrm{p}<0.01,{ }^{* *} \mathrm{p}<0.05, * \mathrm{p}<0.1$. Columns 1 includes all listings while all other columns include only completed loans for which we observe final loan performance status. Columns 1, 2, and 4 are at the listing/loan level, and Column 3 is at the loanmonth level. All regressions control for state dummies, year-week FE, macro variables (except for the IRR regression), duration of auction, and posted credit attributes. Column 3 also control for monthly loan age fixed effects and the loan's contract interest rate. "Mutual friend endorsement + no bid" includes the cases where (1) neither bids on each other or (2) one bids on the other but not vice versa. 
Table 8: Lender response to ever late social loans

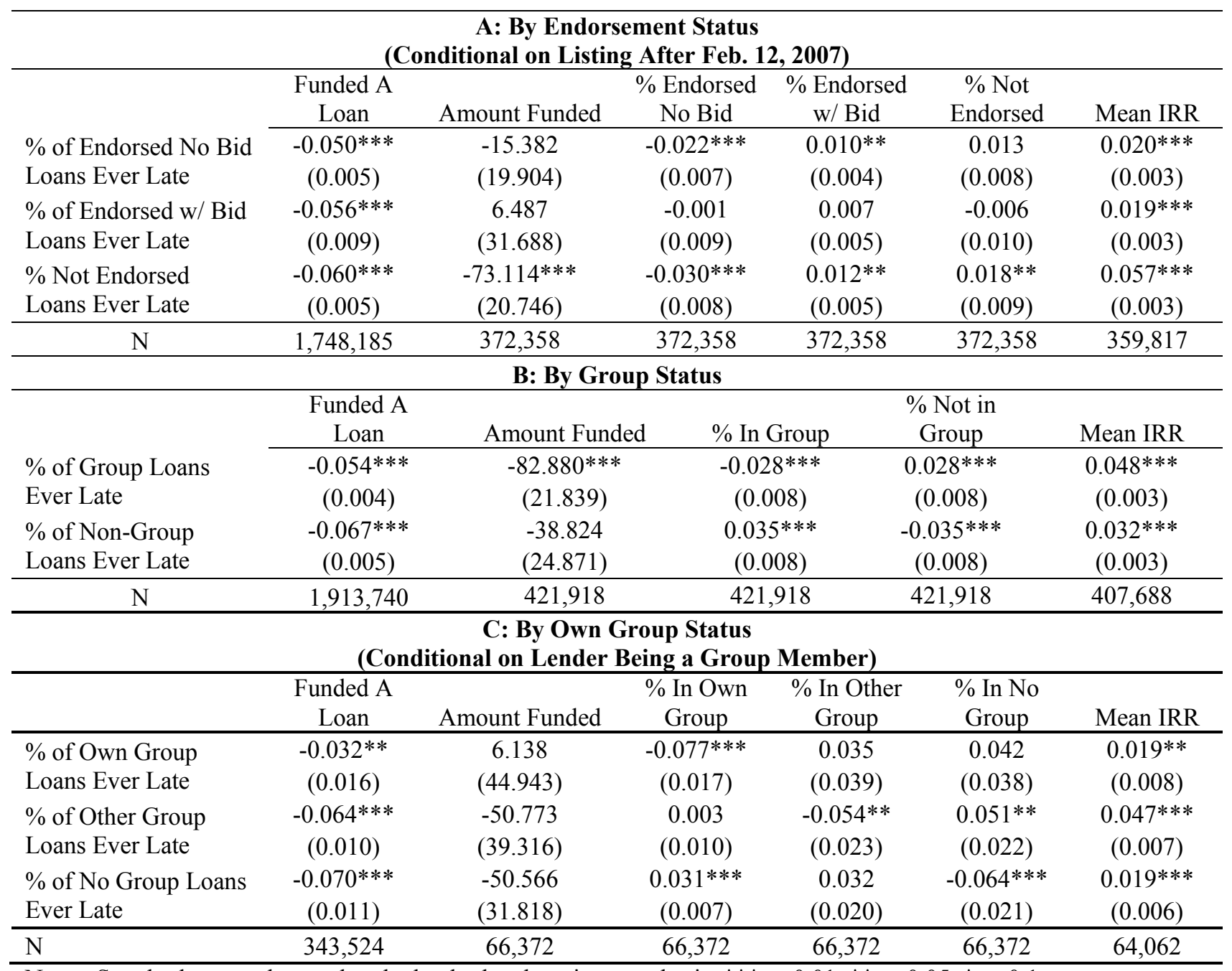

Notes: Standard errors clustered at the lender level are in parenthesis. ${ }^{* * *} \mathrm{p}<0.01,{ }^{* *} \mathrm{p}<0.05,{ }^{*} \mathrm{p}<0.1$. 


\section{Table 9: Within Group Information Transfer}

\section{A: Response to Group Performance, All Group Members}

\begin{tabular}{lccc}
\hline & Funded A Loan & Amount Funded & Mean IRR \\
\hline \% of Group Portfolio & $-0.182^{* * *}$ & -188.957 & $0.084^{* * *}$ \\
Ever Late & $(0.033)$ & $(165.046)$ & $(0.022)$ \\
\% of Own Portfolio & $-0.055^{* * *}$ & $-91.768 * *$ & $0.064 * * *$ \\
Ever Late & $(0.011)$ & $(45.651)$ & $(0.008)$ \\
\hline $\mathrm{N}$ & 343,524 & 66,216 & 63,911 \\
\hline
\end{tabular}

B: Response to Group Performance, Members of Groups with Identifiable Ties

\begin{tabular}{lccc}
\hline & Funded A Loan & Amount Funded & Mean IRR \\
\hline \% of Group Portfolio & $-0.280^{*}$ & -198.840 & 0.034 \\
Ever Late & $(0.091)$ & $(251.309)$ & $(0.039)$ \\
\% of Own Portfolio & $-0.067^{* *}$ & 57.635 & $0.047^{*}$ \\
Ever Late & $(0.028)$ & $(75.876)$ & $(0.017)$ \\
\hline $\mathrm{N}$ & 55,838 & 11,424 & 11,036 \\
\hline Notes: Standard errors clustered at the lender level are in parenthesis. ${ }^{* *} \mathrm{p}<0.01, * * \mathrm{p}<0.05, * \mathrm{p}<0.1$.
\end{tabular}


Figure 1A: Density of Loan Level IRR by Borrower's Group Affilation

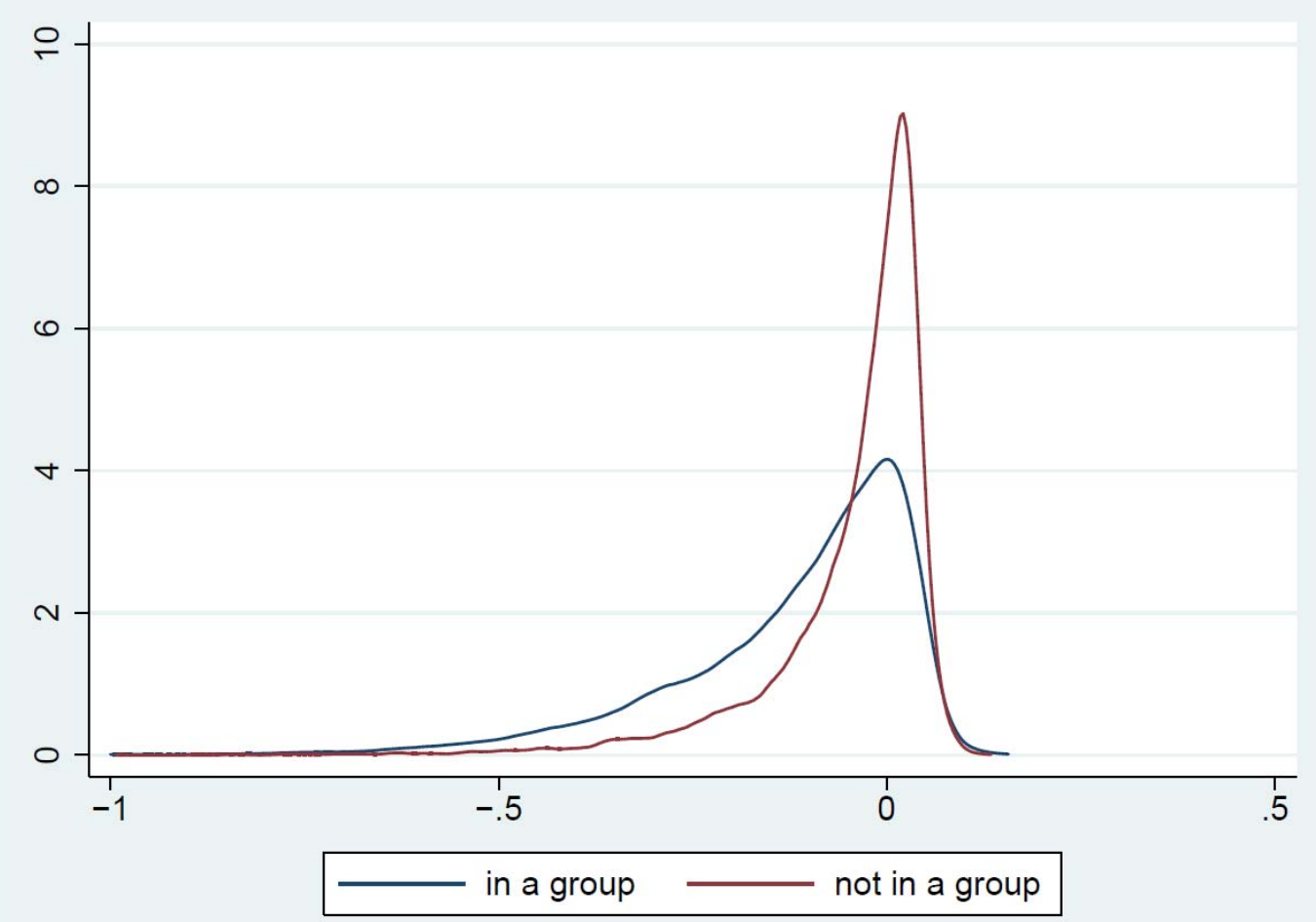

Figure 1B: Mean Loan Level IRR by Borrower's Group Affiliation Over Time

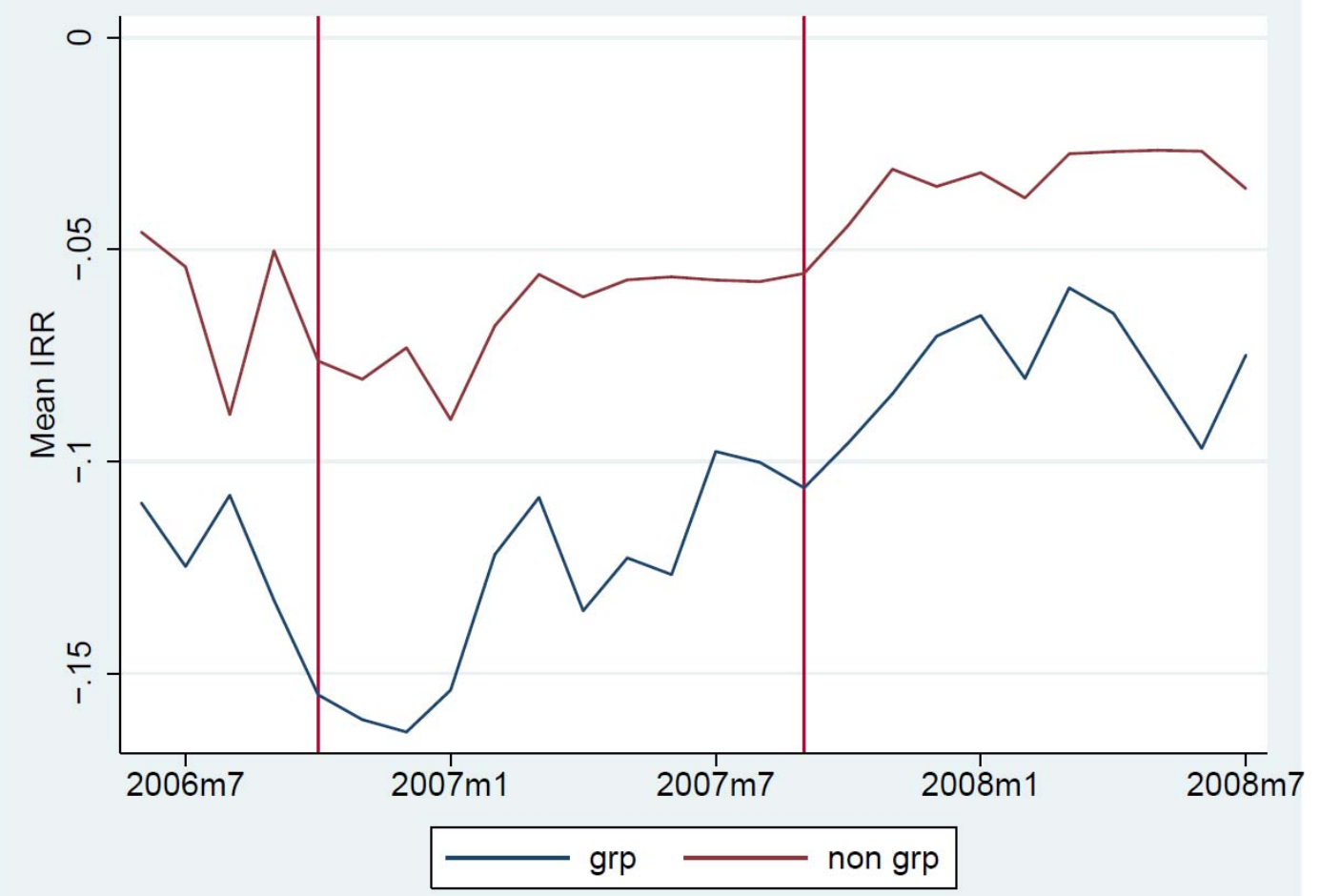


Figure 2A: Density of Loan Level IRR by Borrower's Group Leader Endorsement Status

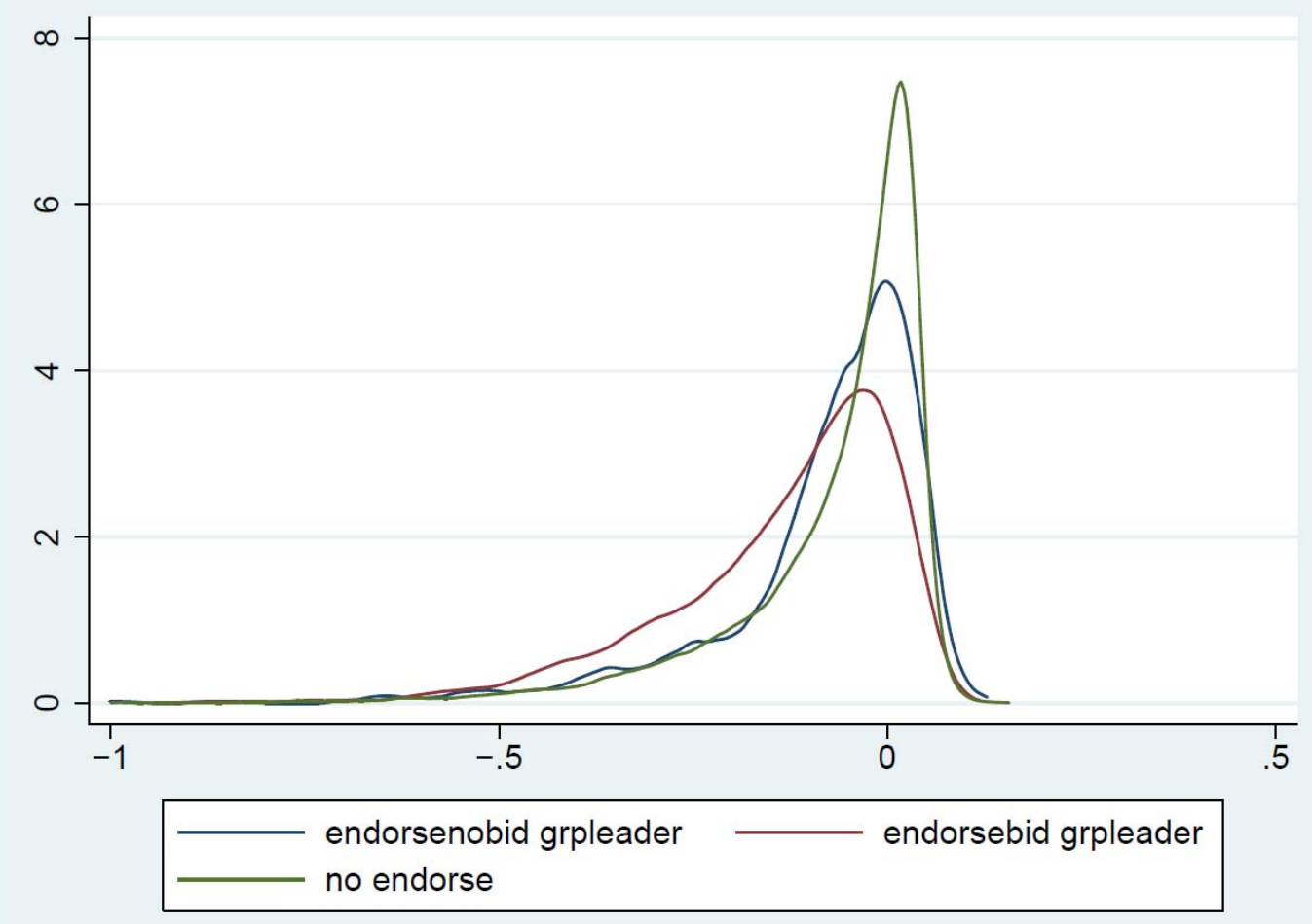

Figure 2B: Mean of Loan Level IRR by Borrower's Group Leader Endorsement Status Over Time

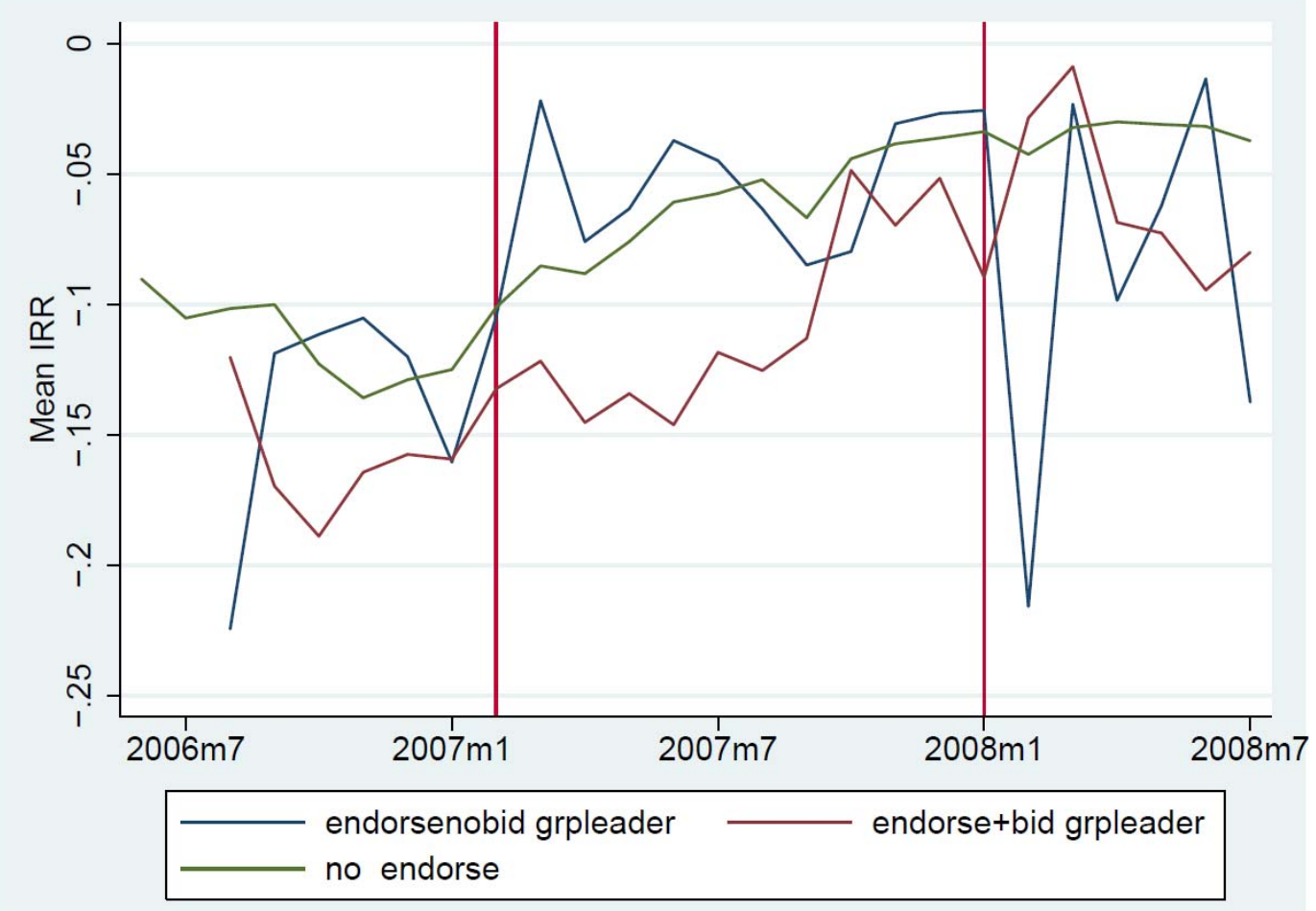


Figure 3A: Density of Loan Level IRR by Borrower's Friend Endorsement Status

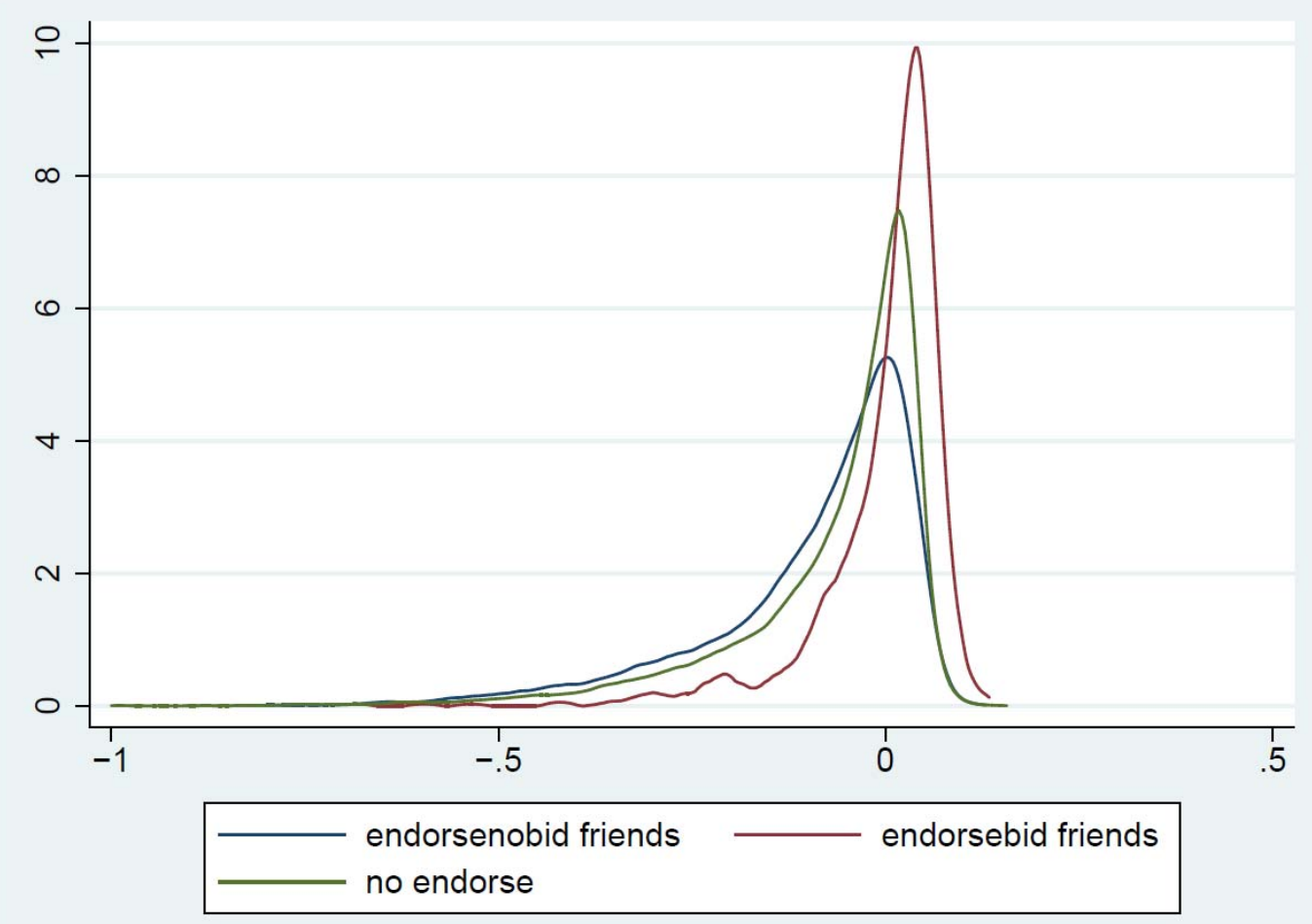

Figure 3A: Mean of Loan Level IRR by Borrower's Friend Endorsement Status Over Time

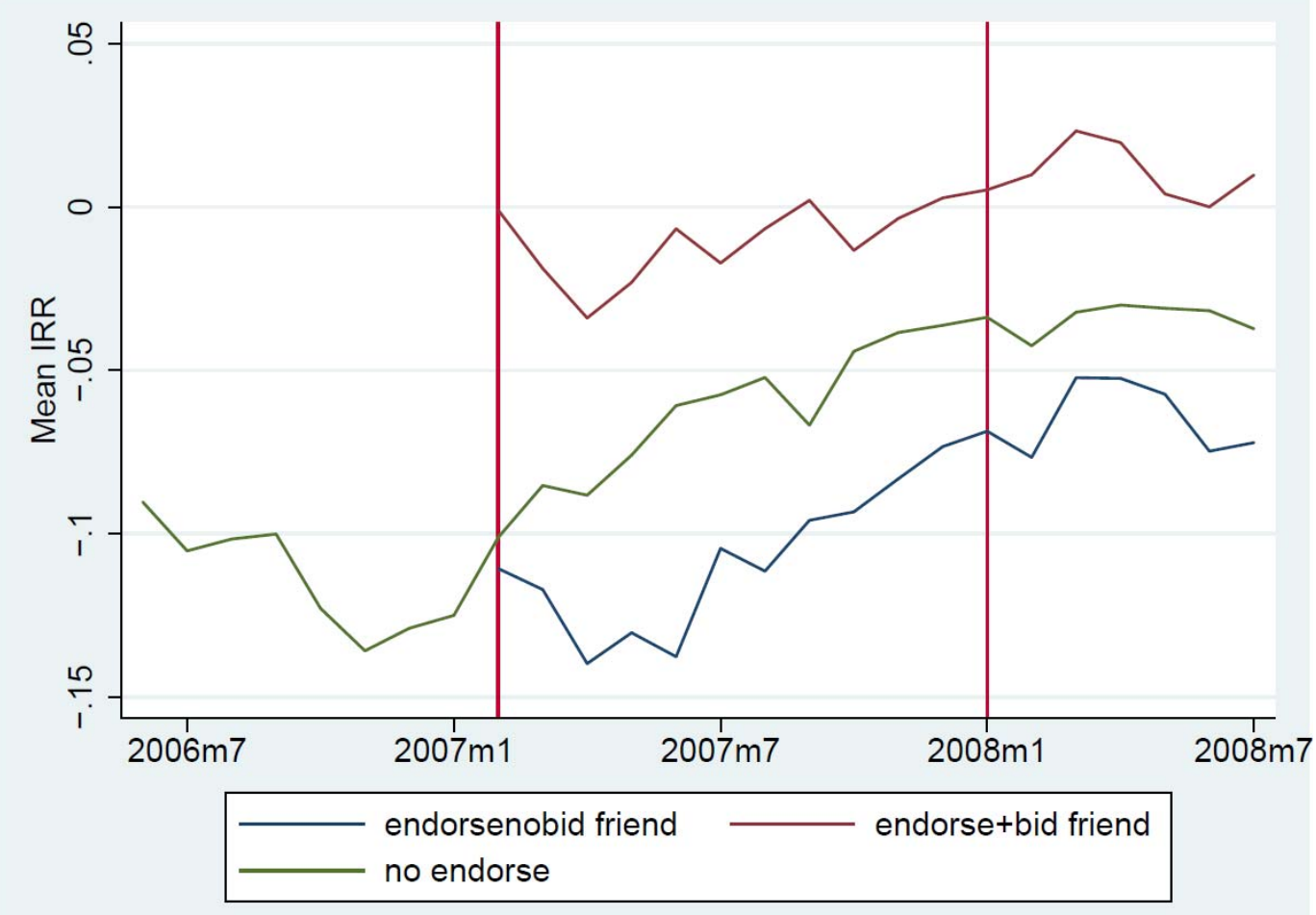




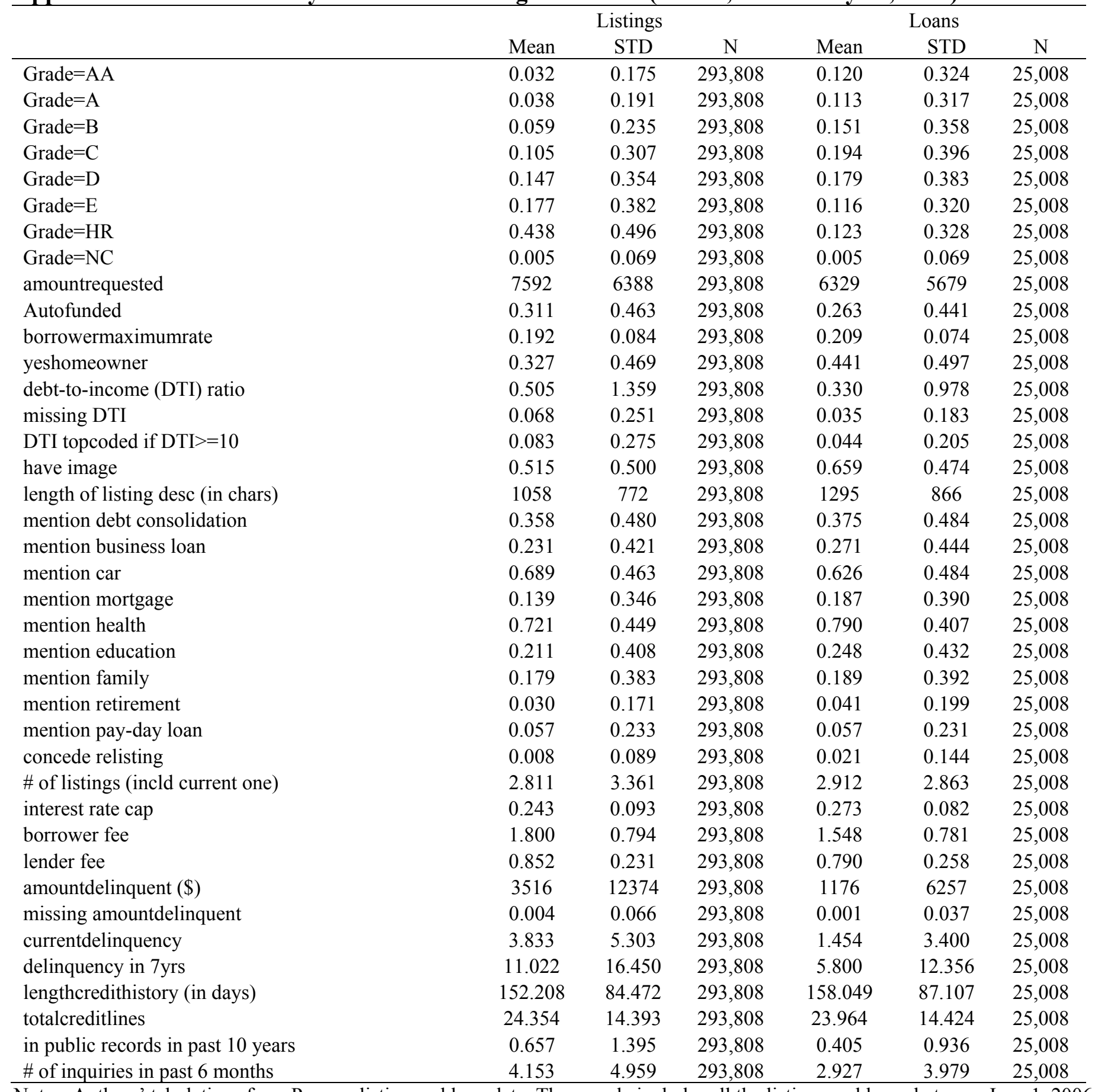

Notes: Authors' tabulations from Prosper listing and loan data. The sample includes all the listings and loans between June 1, 2006 and July 31, 2008 


\section{Appendix Table 2: Summary of Various IRR Versions}

\begin{tabular}{|c|c|c|c|c|c|c|}
\hline Version & $\begin{array}{l}\text { Outcomes } \\
\text { predicted }\end{array}$ & Macro & Mean & Stdev & Minimum & Maximum \\
\hline IRR1 & $\begin{array}{l}\text { payoff, } \\
\text { default }\end{array}$ & real & .0525 & .0758 & -.9804 & .2982 \\
\hline IRR2 & $\begin{array}{l}\text { payoff, } \\
\text { default }\end{array}$ & fixed* & .0997 & .0573 & -.9594 & .3309 \\
\hline IRR3 & $\begin{array}{l}\text { payoff, } \\
\text { misspay }\end{array}$ & real & .0242 & .0908 & -.9992 & .2792 \\
\hline IRR4 & $\begin{array}{l}\text { payoff, } \\
\text { misspay }\end{array}$ & fixed* & .1574 & .0670 & -.9230 & .3820 \\
\hline IRR5 & $\begin{array}{l}\text { payoff, } \\
\text { default or } \\
\text { late }\end{array}$ & real & -.0612 & .1295 & -1.0000 & .1713 \\
\hline IRR6 & $\begin{array}{c}\text { payoff, } \\
\text { default or } \\
\text { late }\end{array}$ & fixed* & -.0750 & .1331 & -1.0000 & .1566 \\
\hline
\end{tabular}

*Fixed macro refers to macro variables fixed as of June 1, 2006. Each version of IRR applies to 23,863 loans. 
Appendix Table 3: Robustness to Exclusion of Listings and Loans with Photos

\begin{tabular}{|c|c|c|c|c|c|}
\hline & I(Funded) & $\begin{array}{c}\text { Contract } \\
\text { Interest Rate }\end{array}$ & I(Default or Late) & I(Paid Off) & IRR \\
\hline & Probit (marg. eff.) & OLS & Probit (marg. eff.) & Probit (marg. eff.) & OLS \\
\hline In a Group & $\begin{array}{c}0.001 * * * \\
(0.000)\end{array}$ & $\begin{array}{c}-0.005 * * * \\
(0.001)\end{array}$ & $\begin{array}{c}0.002 \\
(0.002)\end{array}$ & $\begin{array}{l}-0.001 \\
(0.002)\end{array}$ & $\begin{array}{c}-0.019 * * * \\
(0.001)\end{array}$ \\
\hline Group Leader Endorsement \& No Bid & $\begin{array}{c}0.003 * * * \\
(0.001)\end{array}$ & $\begin{array}{l}-0.001 \\
(0.002)\end{array}$ & $\begin{array}{l}-0.003 \\
(0.005)\end{array}$ & $\begin{array}{c}-0.026 * * * \\
(0.004)\end{array}$ & $\begin{array}{c}0.021 * * * \\
(0.004)\end{array}$ \\
\hline Group Leader Endorsement \& Bid & $\begin{array}{c}0.021 * * * \\
(0.004)\end{array}$ & $\begin{array}{c}-0.003 * * \\
(0.001)\end{array}$ & $\begin{array}{c}0.016^{* * *} \\
(0.003)\end{array}$ & $\begin{array}{c}-0.037 * * * \\
(0.002)\end{array}$ & $\begin{array}{c}-0.014 * * * \\
(0.003)\end{array}$ \\
\hline Friend Endorsement \& No Bid & $\begin{array}{c}0.000 * * \\
(0.000)\end{array}$ & $\begin{array}{l}-0.001 \\
(0.001)\end{array}$ & $\begin{array}{c}-0.014 * * * \\
(0.002)\end{array}$ & $\begin{array}{c}0.006^{* *} \\
(0.002)\end{array}$ & $\begin{array}{c}-0.008 * * * \\
(0.002)\end{array}$ \\
\hline Friend Endorsement \& Bid & $\begin{array}{c}0.018 * * * \\
(0.005)\end{array}$ & $\begin{array}{c}-0.005 * * \\
(0.002)\end{array}$ & $\begin{array}{c}-0.057 * * * \\
(0.005)\end{array}$ & $\begin{array}{c}0.030 * * * \\
(0.005)\end{array}$ & $\begin{array}{c}0.055^{* * *} \\
(0.004)\end{array}$ \\
\hline $\mathrm{N}$ & 142,366 & 8,179 & 294,048 & 294,372 & 8,179 \\
\hline Year-week FE & $\mathrm{X}$ & $\mathrm{X}$ & X & $\mathrm{X}$ & X \\
\hline Loan-age FE & & & $\mathrm{X}$ & $\mathrm{X}$ & \\
\hline Contract Rate Control & & & $\mathrm{X}$ & $\mathrm{X}$ & \\
\hline
\end{tabular}

Notes: The sample includes all the listings and loans between June 1, 2006 and July 31,2008 . Robust standard errors are in parenthesis. $* * *$ p $<0.01, * *$ p $<0.05, *$ $\mathrm{p}<0.1$. Columns 1 includes all listings while all other columns include only completed loans for which we observe final loan performance status. Columns 1,2 , and 5 are at the listing/loan level, and Columns 3-4 are at the loan-month level. All regressions control for state dummies, year-week FE, macro variables (except for the IRR regression), duration of auction, and posted credit attributes. Columns $3-4$ also control for monthly loan age fixed effects and the loan's contract interest rate. 